\title{
Biomass changes and trophic amplification of plankton in a warmer ocean
}

\author{
Guillem Chust ${ }^{1,{ }^{*}}$, J. Icarus Allen ${ }^{2}$, Laurent Bopp ${ }^{3}$, Corinna Schrum ${ }^{4}$, Jason Holt ${ }^{5}$, Kostas Tsiaras ${ }^{6}$, \\ Marco Zavatarelli ${ }^{7,8}$, Marina Chifflet ${ }^{1}$, Heather Cannaby ${ }^{5,9}$, Isabelle Dadou ${ }^{10}$, Ute Daewel ${ }^{4,11}$, \\ Sarah L. Wakelin ${ }^{5}$, Eric Machu ${ }^{12}$, Dhanya Pushpadas ${ }^{4}$, Momme Butenschon $^{2}$, Yuri Artioli ${ }^{2}$, \\ George Petihakis ${ }^{6}$, Chris Smith ${ }^{6}$, Veronique Garçon ${ }^{10}$, Katerina Goubanova ${ }^{10}$, Briac Le Vu ${ }^{10}$, \\ Bettina A. Fach ${ }^{9}$, Baris Salihoglu9 ${ }^{9}$ Emanuela Clementi ${ }^{8, a}$ andXabier Irigoien ${ }^{1,13}$
}

${ }^{1}$ AZTI-Tecnalia, Marine Research Division, Pasaia, Spain

2 Plymouth Marine Laboratory (PML), Prospect Place, Plymouth, UK

${ }^{3}$ IPSL/LSCE (Lab. des Sciences du Climat et de l'Environnement), Orme des Merisiers, Gif-sur-Yvette, France

${ }^{4}$ Geophysical Institute, University of Bergen (GFI-UIB), Bergen, Norway

5 National Oceanography Centre, Liverpool, UK

${ }_{7}^{6}$ Hellenic Centre for Marine Research (HCMR), Anavyssos, Greece

7 Alma Mater Studiorum Universita' di Bologna, Dipartimento di Fisica e Astronomia, Viale Berti-Pichat 6/2, Bologna, Italy

${ }^{8}$ Alma Mater Studiorum Universita' di Bologna sede di Ravenna, Centro Interdipartimentale di ricerca sulle Scienze Ambientali, Ravenna, Italy

9 Institute of Marine Sciences, Middle East Technical University (METU), Erdemli-Mersin, Turkey

10 Laboratoire d'Etudes en Géophysique et Océanographie Spatiale (LEGOS, UMR5566, IRD/CNES/CNRS/UPS), OMP, Toulouse, France

${ }_{11}^{11}$ Nansen Environmental and Remote Sensing Center, Bergen, Norway

12 Laboratoire de Physique des Océans (UMR6523, CNRS/Ifremer/IRD/UBO), Plouzané, France

13 Red Sea Research Center, King Abdullah University of Science and Technology (KAUST), Thuwal, Saudi Arabia

a Present address : Istituto Nazionale di Geofisica e Vulcanologia, sezione di Bologna, Bologna, Italy

*: Corresponding author : Guillem Chust, tel. (+34) 667174396 ; fax (+34) 946572555 ;

email address : gchust@azti.es

\begin{abstract}
:
Ocean warming can modify the ecophysiology and distribution of marine organisms, and relationships between species, with nonlinear interactions between ecosystem components potentially resulting in trophic amplification. Trophic amplification (or attenuation) describe the propagation of a hydroclimatic signal up the food web, causing magnification (or depression) of biomass values along one or more trophic pathways. We have employed 3-D coupled physical-biogeochemical models to explore ecosystem responses to climate change with a focus on trophic amplification. The response of phytoplankton and zooplankton to global climate-change projections, carried out with the IPSL Earth System Model by the end of the century, is analysed at global and regional basis, including European seas (NE Atlantic, Barents Sea, Baltic Sea, Black Sea, Bay of Biscay, Adriatic Sea, Aegean Sea) and the Eastern Boundary Upwelling System (Benguela). Results indicate that globally and in Atlantic
\end{abstract}


Margin and North Sea, increased ocean stratification causes primary production and zooplankton biomass to decrease in response to a warming climate, whilst in the Barents, Baltic and Black Seas, primary production and zooplankton biomass increase. Projected warming characterized by an increase in sea surface temperature of $2.29 \pm 0.05^{\circ} \mathrm{C}$ leads to a reduction in zooplankton and phytoplankton biomasses of $11 \%$ and $6 \%$, respectively. This suggests negative amplification of climate driven modifications of trophic level biomass through bottom-up control, leading to a reduced capacity of oceans to regulate climate through the biological carbon pump. Simulations suggest negative amplification is the dominant response across $47 \%$ of the ocean surface and prevails in the tropical oceans; whilst positive trophic amplification prevails in the Arctic and Antarctic oceans. Trophic attenuation is projected in temperate seas. Uncertainties in ocean plankton projections, associated to the use of single global and regional models, imply the need for caution when extending these considerations into higher trophic levels.

Keywords: ecosystem model ; food web ; plankton ; primary production ; sea warming ; trophic amplification 


\section{Abstract}

Ocean warming can modify the ecophysiology and distribution of marine organisms, and relationships between species, with nonlinear interactions between ecosystem components potentially resulting in trophic amplification. Trophic amplification (or attenuation) describe the propagation of a hydroclimatic signal up the food web, causing magnification (or depression) of biomass values along one or more trophic pathways. We have employed 3-D coupled physical-biogeochemical models to explore ecosystem responses to climate change with a focus on trophic amplification. The response of phytoplankton and zooplankton to global climate-change projections, carried out with the IPSL Earth System Model by the end of the century, is analysed at global and regional basis, including European seas (NE Atlantic, Barents Sea, Baltic Sea, Black Sea, Bay of Biscay, Adriatic Sea, Aegean Sea) and the Eastern Boundary Upwelling System (Benguela). Results indicate that globally and in Atlantic Margin and North Sea, increased ocean stratification causes primary production and zooplankton biomass to decrease in response to a warming climate, whilst in the Barents, Baltic and Black Seas, primary production and zooplankton biomass increase. Projected warming characterised by an increase in sea surface temperature of $2.29 \pm 0.05{ }^{\circ} \mathrm{C}$ leads to a reduction in zooplankton and phytoplankton biomasses of $11 \%$ and $6 \%$, respectively. This suggests negative amplification of climate driven modifications of trophic level biomass through bottom-up control, leading to a reduced capacity of oceans to regulate climate through the biological carbon pump. Simulations suggest negative amplification is the dominant response across $47 \%$ of the ocean surface and prevails in the tropical oceans; whilst positive trophic amplification prevails in the Arctic and Antarctic oceans. Trophic attenuation is projected in temperate seas. Uncertainties in ocean plankton projections, associated to the 
use of single global and regional models, imply the need for caution when extending these considerations into higher trophic levels. 


\section{Introduction}

The upper global ocean $(75 \mathrm{~m})$ warmed by $0.11{ }^{\circ} \mathrm{C}$ per decade over the period $1971-2010$ (Rhein et al., 2013), and will continue to warm during the 21st century (Collins et al., 2013). Temperature is a key factor in determining marine species distribution, their interactions and the overall trophic state of the ecosystem (Cury et al., 2008). Although ocean warming is known to modify and modulate the ecophysiology and distribution of marine organisms (e.g. Richardson, 2008; Cheung et al., 2010, 2012), the nature of changes in ocean productivity and food web structure triggered by ocean warming remain uncertain (Reid et al., 2009; Philippart et al., 2011). Warming may trigger nonlinear responses in the way ecosystem components interact, involving ecological thresholds (Beaugrand et al., 2008), and trophic amplifications (Kirby et al., 2009). The term "trophic amplification" (or "attenuation") has been proposed by Kirby \& Beaugrand (2009) to account for the bottom-up propagation of the hydroclimatic signal along the trophic web, magnifying (or depressing) biomass values along one or more trophic pathways. Such propagation can modulate shifts between trophic regimes; for instance, warming favoured lower trophic level groups in the North Sea (Kirby et al., 2009). The impacts of climate change on marine trophic amplification, however, have been scarcely explored, with previous works restricted to regional studies of the North Sea (e.g. Kirby \& Beaugrand, 2009; and Lindley et al., 2010), or Antarctica (Forcada et al., 2006), in addition to studies of coastal marine communities using mesocosm experiments (e.g. Hansson et al., 2013; and Jochum et al., 2012). In the context of the continuous alteration of marine ecosystems by human activities and especially fishing (Pauly et al., 1998), future projections of ocean productivity, based on trophic interactions, are required for a comprehensive assessment of ocean health and the goods and services it provides (Halpern et al., 2012). 
Three-dimensional hydrodynamic models coupled to complex ecosystem models provide powerful tools for climate impact assessment. While model development is still an evolving field of research, and uncertainties associated with coupled modelling studies are well documented, such tools allow assessment of the response of highly nonlinear systems to perturbations in environmental forcing. Previous studies have been limited by the resolution of the atmosphere-ocean general circulation models (AOGCMs), which are inadequate for predicting changes in ocean current circulation and stratification on regional scales (Allen et al., 2010). Dynamical downscaling of global climate models, with the aim of achieving improved process representation at the regional scale, is necessary in order to increase the level of confidence attributed to regional climate projections (e.g. Wang et al., 2004; Goubanova et al., 2011; Echevin et al., 2012), and hence for defining local adaptation strategies to climate change.

Here, regionally specific coupled modelling systems are used to assess the potential ecosystem response to a projected future climate scenario. Ecosystem responses are then classified as trophic amplification or attenuation. To this end, 3-D coupled physicalbiogeochemical models were forced by global climate simulations, which represent 'typical' conditions both in the past and under various atmospheric composition scenarios (defined in IPCC-AR4, 2007). The ecosystem response to climate-change projections by the end of the century (2080-2100 relative to 1980-2000) is analysed both at a global scale and on a regional basis, with the regional studies covering a large gradient of environmental conditions within European seas (NE Atlantic, Barents Sea, Baltic Sea, Black Sea, Bay of Biscay, Adriatic Sea, North Aegean Sea) and including the Benguela upwelling system as one of the most productive upwelling systems of the global ocean (Carr \& Kearns, 2003; Chavez \& Messié, 2009). In this region-by-region comparative analysis, we propose a framework to assess the 
processes of amplification and attenuation in the ecosystem response from lower to higher trophic levels (Figure 1a). In this approach, the response of a given trophic level descriptor (e.g. biomass) to climate change is compared with the response of the immediately lower trophic level. Thus, the domain can be split into two main control types: top-down and bottom-up control. In turn, bottom-up control encompasses three classes of trophic propagation: amplification (i.e. the absolute fractional change in biomass of the higher trophic level is greater than that of the lower trophic level), attenuation (i.e. the absolute fractional change in biomass of the higher trophic level is smaller than that of the lower trophic level) and proportional response (i.e. the absolute fractional change in biomass of the higher trophic level is similar to that of the lower level); all three classes may have corresponding positive or negative cases. The domain of top-down control may describe either the intensification or the release of grazing pressure. 


\section{Material and Methods}

\section{Coupled hydrodynamic-ecosystem models}

Three-dimensional coupled hydrodynamic ecosystem model simulations have been performed within each region and at the global scale (Table 1). In essence, we have coupled two types of models: 1) hydrodynamic models forced by both reanalysis data (for validation purposes) and a coupled ocean-atmosphere general circulation model (OAGCM) (for exploring the behaviour of the system under possible future climate change conditions), and 2) Lower trophic level models (describing biogeochemical cycling, phytoplankton and zooplankton interactions, and for the cases of ERSEM and BFM, bacteria.

Different hydrodynamic models have been used: Proudman Oceanographic Laboratory Coastal Ocean Modelling System (POLCOMS; Holt \& James, 2001), NEMO (Madec, 2008), Regional Ocean Model System (ROMS; Shchepetkin \& McWilliams, 2005) without and with its version with the 2-way nesting capability (ROMS-AGRIF; Penven et al., 2006a; Debreu et al., 2012), and the Princeton Ocean Model (POM; Blumberg \& Mellor, 1987). Hydrodynamic models differ in details of the numerical solution of the equations of motion, spatial and vertical resolution. The physical variables analysed were the following: sea surface temperature and potential energy anomaly and mixed layer depth as indicators of stratification intensity and mixing, respectively (Holt et al., 2010).

All lower trophic level models used divide the ecosystem into several nutrient, producer and consumer compartments, and cycles with one or more elements among these. They differ in the number and type of groups of phytoplankton and zooplankton, fixed or variable C:N, and 
whether they include or not explicit microbial loop (bacteria), temperature dependence rates for phytoplankton growth, and benthic biology (Table 1). While most of models divide phytoplankton and zooplankton into two size classes, i.e. small and large, other split them in more groups (e.g., until five classes in the case of BIMS-ECO zooplankton). Different lower trophic level models are used: European Regional Seas Ecosystem Model (ERSEM; Blackford et al., 2004; Petihakis et al., 2002), Pelagic Interaction Scheme for Carbon and Ecosystem Studies (PISCES; Aumont \& Bopp, 2006), Nitrogen Phytoplankton Zooplankton Detritus (NPZD; Franks et al., 2002), Biogeochemical model for Eastern Boundary Upwelling Systems (BioEBUS; Gutknecht et al., 2013a and 2013b), Black Sea Integrated Modeling System (BIMS-ECO (Oguz et al., 2001), BFM (Biogeochemical Flux Model, Vichi et al. 2007), ECOSMO (ECOSystem MOdel), which is a coupled physical-biogeochemical model system (Schrum et al., 2006, Daewel \& Schrum, 2013). The biogeochemical variables analysed are the following: net primary production, phytoplankton biomass and zooplankton biomass.

More details regarding model setup and hindcast simulation skill assessment are available online (MEECE report, 2013) and published for some of the regional models (see Daewel \& Schrum, 2013 for the Baltic Sea; Holt et al., 2012 for the NE Atlantic; Aumont et al., 2008 and Rodgers et al., 2008 for the global model; Årthun et al., 2011, 2012 and Årthun \& Schrum, 2010 for the Barents Sea, and Tsiaras et al., 2014 for Aegean Sea). Most of the models have been validated using Taylor diagrams (Taylor, 2001) (quantified in terms of their correlation and the amplitude of their variations represented by their standard deviation) for several physical (temperature, salinity), biological (phytoplankton and zooplankton) variables, and nutrients. The Table 1 presents the skill assessment for sea surface temperature and 
chlorophyll concentration, which indicate moderate to good agreement between model and observations.

\section{Climate scenarios}

To perform and compare the regional projections and their ecosystem response, regional physical-biogeochemical models were forced with IPSL-CM4 climate simulations (CNTRL and A1B) using a delta change (monthly changes) time-slice experiment: simulations were run between 1980 and 2000 and between 2080 and 2100, with variable spin-up (e.g. 10 years before the period starting year, or repeating the starting year of the period). For the global model, however, simulations were run for the entire period from 1860 to 2100 , and only years 1980-to-2000 and years 2080-to-2100 were kept for the subsequent analysis. IPSL-CM4 is an Earth system model (ESM), which considers in addition to atmospheric and oceanic physical variables also the ocean and land biogeochemistry. Nutrient boundary conditions from the IPSL-CM4 have been used for the regional simulations. The CNTRL simulation is forced by the IPSL-CM4 20C model for the present day period between 1980 and 2000. A1B is a future climate scenario representative of possible conditions between 2080 and 2100 under a business as usual emissions scenario: SRES (Special Report on Emission Scenarios; Nakicenovic and Swart, 2000) A1B socio-economic 'story line'. In terms of the range of GHG emissions scenarios defined by the SRES report, A1B describes a relatively moderate increase in anthropogenic GHG emissions throughout the 21 st century $\left(850 \mathrm{ppm}\right.$ of $\mathrm{CO}_{2}$-eq concentrations in 2100). Specifically, we have used the difference between the future A1B scenario (2080-2100) and the CNTRL simulation (1980-2000), to assess climate change impacts at the end of the century. For sea surface temperature, we have calculated the absolute difference, and for the phytoplankton and zooplankton biomasses we used the fractional 
change: $\left(\operatorname{Scenario}_{(2080-2100)} / \operatorname{Control}_{(1980-2000)}\right)-1$ (see Holt et al., 2012, -1 to 0: decrease, positive values: increase). The trophic ratio (zooplankton biomass divided by phytoplankton biomass) has been also calculated.

Trophic amplification analysis

The processes of amplification and attenuation in the ecosystem response were assessed by comparing the response of the zooplankton biomass (fractional change) to climate change with the response of the phytoplankton biomass (Figure 1). The domain is split into two main control types: top-down and bottom-up control (Figure 1a). In turn, bottom-up control encompasses three classes of trophic propagation with corresponding positive or negative cases: positive amplification (i.e. the phytoplankton biomass increases and the fractional change in zooplankton biomass is greater than that of the phytoplankton biomass), negative amplification (the phytoplankton biomass decreases and the fractional change in zooplankton biomass is less than that of the phytoplankton biomass), positive attenuation (i.e. both phytoplankton and zooplankton biomass increase and the fractional change in zooplankton biomass is smaller than that of the phytoplankton biomass), negative attenuation (both phytoplankton and zooplankton biomass decrease and the fractional change in zooplankton biomass is greater than that of the phytoplankton biomass), positive proportional response (i.e. the increase of zooplankton biomass fractional change is similar to that of the phytoplankton, taking a threshold of \pm 0.01 ), and negative proportional response (the decrease of zooplankton biomass fractional change is similar to that of the phytoplankton, taking a threshold of \pm 0.01 ). The domain of top-down control may describe either the intensification or the release of grazing pressure (i.e. implying a trophic cascade). Following this approach, we have undertaken three types of analysis: 1) zooplankton is plotted against phytoplankton 
biomass fractional change considering overall average values for each case study; 2) zooplankton is plotted against phytoplankton biomass fractional change for each grid cell of the global model; and 3) the geographic representation of trophic propagation. 


\section{Results and discussion}

\section{Hydroclimatic changes}

The physical response of the oceans to climate change and its impact on primary production is complex with multiple, nuanced interactions involving temperature effects on metabolic rates, stratification and change to patterns of nutrient resupply (e.g. Taucher \& Oschlies, 2011; Rykaczewski \& Dunne, 2011). It is not our intention to explore these interactions in detail as this is considered elsewhere on a region-by region basis (e.g. Holt et al., 2012; Daewel \& Schrum, 2013). Here we briefly describe some basic regionally averaged metrics for the subsequent discussion on trophic interactions. Under the climate change scenario studied here, sea warming is a common feature expected in all regions and at global scale (Table 2) by the end of the century. The global model projects a mean global sea surface warming signal of $2.29 \pm 0.05{ }^{\circ} \mathrm{C}$ under an A1B emissions scenario. Some regions of the global ocean are expected to warm moderately (e.g. surrounding the Antarctic continent), whereas other regions show more substantial warming (e.g. in the subarctic and in the Gulf Stream, where warming of more than $4^{\circ} \mathrm{C}$ is projected before the end of the century). Global mixed layer depth is projected to decrease by $8.4 \%$ on average, indicating increased global stratification. The projected increase of sea temperature in European regions $\left(1.02-3.64{ }^{\circ} \mathrm{C}\right.$, mean: $\left.2.43{ }^{\circ} \mathrm{C}\right)$ is slightly higher than the global mean, a result consistent with analysis of recent trends by Good et al. (2007) and Holt et al. (2012). In the Barents Sea, projections of oceanic warming will be accompanied by a significant sea ice decrease, as in the Baltic Sea, and by an increase of Atlantic water inflow. The Baltic Sea was projected to experience freshening and increasing surface nutrients, largely driven by increased winter ventilation due to changing winds. The freshening is due to a combination of wind field changes and increases in 
precipitation. The mechanisms have earlier been described by Schrum (2001). In the NE Atlantic, the main physical changes were an increase in sea surface temperature (larger in the North of the domain than in the South), freshening over the northwest European continental shelf and in the Bay of Biscay, and an increase in surface salinity in the open ocean between Iceland and Norway. A small increase in seasonal stratification that starts earlier in the year, is excepted in the Bay of Biscay and the Celtic Seas. Climate simulations of the NE Atlantic suggest the region will be more stratified under the future scenario; especially off-shore (where mixed layer depth decreases by $48 \%$ ), whilst the mixed layer depth of shelf waters decreases by only $6 \%$. The Black Sea was projected to experience increased stratification (indicated by a potential energy anomaly increases of $23 \% \pm 0.01$ ), which resulted in reduced nutrient pumping into the surface mixed layer and increased the residence time of riverine nutrients within the surface mixed layer, the net result of which was a $4 \%$ increase in nitrate availability within the upper $30 \mathrm{~m}$ of the water column.. The Adriatic Sea was projected to experience a warming of about $1.75^{\circ} \mathrm{C}$. In the North Aegean Sea, an increase in sea surface temperature of $1.02^{\circ} \mathrm{C}$ (Table 2) and stratification (indicated by a mixed layer depth decreases of $6 \%$ ) were projected, while salinity increases (0.05 psu on average) in coastal river influenced areas due to decreasing river runoff and precipitation. The Benguela upwelling system was projected to experience an overall sea surface warming $\left(+1.4^{\circ} \mathrm{C}\right)$, and a decrease of trade winds magnitude $(-10 \%)$ and of minimum oxygen concentrations (-20 to -30 $\left.\mathrm{mmol} / \mathrm{m}^{3}\right)$

\section{Response of plankton}

Globally and in temperate European seas (Atlantic Margin and North Sea), and the Benguela upwelling system, primary production was projected to decrease (3-12\%) on average under a 
future A1B climate change scenario (Table 2, Figure 2, Figure 3), whilst in the most northern European sea (the Barents Sea) and in the Baltic Sea and Black Sea, primary production was projected to increase (3-15\%). Global simulations suggested primary production will decrease by $9 \%$ and zooplankton biomass by $11 \%$. This corresponds to a slight change in the trophic ratio (zooplankton biomass divided by phytoplankton biomass) from 1.74 to 1.66 (approx. a 5\% change, Table 2), which indicates a slight re-structuring of the food web. The general reduction in primary production is attributed to the reduced input of nutrients into the euphotic zone as a result of enhanced stratification. Our analysis is in agreement with most of coupled climate-marine biogeochemical models in terms of global declining response of primary production to climate change in the open ocean (e.g. Bopp et al., 2001, 2013; Steinacher et al., 2010; Vichi et al., 2011), but relative and absolute magnitudes differ among models and regions. As in our case, multi-model comparisons (Steinacher et al., 2010, and Bopp et al., 2013) and the marine ecosystem model of Follows et al. (2007) with modifications (Dutkiewicz et al., 2013), which incorporate 100 phytoplankton types, have shown that decrease in primary production is found in the tropical Indian, tropical Western Pacific, tropical Atlantic, and North Atlantic, while increasing in the Arctic Ocean and in parts of the Southern Ocean. On the other hand, some studies (e.g. Vichi et al., 2011; Ruggio et al., 2013) found that some parts of the equatorial Pacific may increase the net primary production following changes in the subsurface equatorial circulation and enhanced iron availability from extratropical regions.

The Adriatic Sea constitutes an apparent exception with respect to the general pattern of change in primary production, being a "southern" sea which is projected to experience a general increase in the basin averaged primary production, phytoplankton biomass remains unchanged and a slight increase in zooplankton biomass. Biogeochemical changes occurring 
in the Adriatic Sea are strongly influenced by riverborne nutrient inputs and that policy measures aiming to reduce the phosphorus content in river waters started in the 1980's. Nutrient river load data used to force the Adriatic Sea hindcast simulations (Ludwig et al., 2009) represented the decrease in nutrient input to the region resulting from policy changes. The nutrient load reduced $30 \%$ between the 80 's and the last decade of the $20^{\text {th }}$ century, a value in general agreement with the estimates of the northern Adriatic river load by Degobbis \& Gilmartin (1990) and Cozzi \& Giani (2011). This change in the biogeochemical forcing accounts for the decrease in simulated phytoplankton biomass and primary production during the 1980-2000 hindcast simulation period, a trend also confirmed by observations (Mozetič et al., 2009). The $21^{\text {st }}$ century Adriatic Sea simulations carried out under the A1B scenario for atmospheric forcing included also river nutrient load computed under the "Business as usual" assumption (Ludwig et al., 2010). This forcing data set includes a slight increase of the nutrient load compared with the load of the last decade of the $20^{\text {th }}$ century, accounting for the simulated $21^{\text {st }}$ century increase of primary production occurring despite the upper layer warming and enhanced stratification.

Contrastingly, in subarctic regions such as the Barents Sea, in semi-enclosed seas such as the Baltic and Black Sea and in shelf regions such as Southern North Sea, Celtic Sea, Irish Sea, English Channel and Armorican Shelf, primary production and consequently, zooplankton biomass, increases with climate change. In the case of the Barents Sea and the northern Baltic Sea, a reduction in sea ice cover allows the regions to be more productive since it prolongs the growing season. However, the major contribution to increased production in the Baltic Sea is the increased winter ventilation which increases nutrient concentration in the euphotic zone. In the highly eutrophic Black Sea which is dominated by the Danube plume, increased stratification increases the residence time of riverine nutrients within the euphotic zone, 
resulting in increased nitrate concentrations within the surface mixed layer which supports increased primary production. The mechanisms responsible for the changes at a regional scale can be associated with two different hydrographical processes that lead to two different productivity regimes at a global scale (Falkowski et al., 1998; Behrenfeld et al., 2006; Steinacher et al., 2010; and Henson et al., 2010). The first proposed regime is dominant in the low- and mid-latitude ocean and in the North Atlantic and it is characterised by reduced input of macro-nutrients into the euphotic zone related to enhanced stratification, combined with a reduction in the mixed layer depth and slowed circulation causing a decrease in net primary production. These regions will become increasingly oligotrophic. The second regime is proposed for the Arctic Ocean and areas of the Southern Ocean: an alleviation of light and/or temperature limitation leads to an increase in net primary production. This prevails in colder well-mixed waters, i.e. with sustained nutrient input, where warming is expected to drive moderate stratification that is beneficial to phytoplankton growth. However, the specific physical and biogeochemical processes dominant within each region will generally modulate this overall pattern. High spatial variations in plankton biomass change are found within individual regions, as seen in the European seas and the Benguela upwelling system (Figure 3). The map showing projected changes in primary production in the Black Sea provides a good example of the small-scale spatial variability that may exist in the response of primary producers to climate change (Figure 4). Whilst overall primary production is projected to increase $(5 \%)$ and zooplankton biomass is projected to not change significantly, plankton biomass in the regions adjacent to the Crimean Peninsula exhibited an increasing trend and a decrease in phytoplankton biomass in the southwest of the basin near the Bosphorus is projected (Figure 4). While the basin scale response of the Black Sea is linked to increased stratification, the regional variability in the response of the Black Sea is attributed to changes 
in the wind driven circulation, which in turn influences the distribution of Danube plume waters.

The phytoplankton and zooplankton biomass changes of the global model were also compared with regional models at their corresponding areas (Table 2), except for the Celtic Sea, Black Sea, Adriatic Sea and Aegean Sea due to their small size in relation to the global model resolution. In both global and regional models, phytoplankton and zooplankton biomasses decrease in the Atlantic Margin, North Sea and Benguela upwelling. In the Barents Sea, global and regional only agree in the increase of zooplankton biomass. On the contrary, global model projection trends did not agree in the Baltic Sea (ECOSMO model) and in one of the two models of the Bay of Biscay (ROMS-NPZD). The discrepancies should be related to model resolution, model type and model inputs (such as river discharges that are better represented in regional models). Concerning the biogeochemical model, all three models (PISCES, ECOSMO and NPZD) divide phytoplankton and zooplankton into two size classes, although only PISCES and NPZD have temperature dependent rates for phytoplankton growth (Table 1). The coarse resolution of the global model $(\sim 220 \mathrm{~km}$ for the global model compared to $2-12 \mathrm{~km}$ for regional models) might not resolve in small, complex and highly terrestrial-influenced areas for hydro-climate processes, such as local thermohaline stratification and nutrients inputs both due to river discharges, mesoscale activity over the slope, mixing, upwelling, that are responsible for the variability in planktonic production and dynamics. Further research should focus on modelling the response of the oceanic productivity to climate change using multi-models estimates and enhanced resolution to represent the scales of coastal upwelling and other mesoscale phenomena such as eddies (Bopp et al., 2013). 


\section{Trophic amplification}

At a global scale, the overall change in zooplankton biomass (-11\%) is more pronounced than the change in phytoplankton biomass (-6\%) (Figure 2, Table 2), suggesting a potential amplification of the climate change driven modifications of trophic level biomass through bottom-up control. This negative amplification from phytoplankton to zooplankton biomass (predominantly in the tropical oceans, see Figure 5) is confirmed when analysing spatial variability in the global model (Figure 1c, the response over $47 \%$ of the total area is classed as negative amplification). On the other hand, when phytoplankton biomass changes positively, zooplankton biomass is prone to increase either by a larger fraction than phytoplankton (amplifying; seen over 9\% of the global model domain, mainly in the subarctic and Antarctic oceans) or proportionally (seen over $12 \%$ of the global model domain). Attenuation is found in temperate seas between positive amplification in the poles and negative amplification in the tropics. Positive and negative attenuation are distributed latitudinally in the Northern hemisphere, with positive attenuation at higher latitudes and negative adjacent to tropics. The top-down control is not common (occurring 10\%) in the global ocean, probably because climate change propagates from physics to lower trophic levels and, subsequently, to higher ones; i.e. as bottom-up control.

A potential explanation for the global spatial pattern of the trophic amplification (both positive and negative) might be associated with the non-linear relationship between zooplankton and phytoplankton biomass and the environmental conditions allowing for phytoplankton growth. In the NEMO-PISCES global model, the grazing function of microzooplankton and mesozoopoankton, defined following Fasham et al. (1993), is a Michaelis-Menten type (Aumont \& Bopp, 2006), i.e. the zooplankton grazing rate saturates 
with both diatom and nanophytoplankton biomass. Thus, small variations of phytoplankton biomass in cases of low values imply stronger variations of zooplankton biomass (steep slope) than in cases of high values of phytoplankton biomass (flat slope), assuming constant all other factors (e.g., nutrients, light, temperature). Analysing the global spatial pattern, in situations where phytoplankton biomass is low (mean annual phytoplankton biomass less than circa $2000 \mathrm{mgC} / \mathrm{m}^{2}$, prevailing in tropical ocean and subpolar regions, see Figure 6a), zooplankton biomass has a steeper (slope $=2.83$ ) and closer relation to phytoplankton than in areas where phytoplankton biomass is higher than $2000 \mathrm{mgC} / \mathrm{m}^{2}$ (slope $=0.84$, Figure $6 \mathrm{~b}$ ) such as the temperate regions. This might explain why an increase in phytoplankton biomass in subpolar regions drives a proportionally higher increase in zooplankton biomass, while in tropical oceans a decrease in phytoplankton triggers a larger decrease in zooplankton biomass. In temperate regions, phytoplankton would not be a limiting factor for zooplankton on average (Figure 6a), and the relation between the two trophic levels is flatter and weaker (Figure 6b), which may explain why in those regions the trophic response is variable encompassing all types (i.e., attenuation, proportional, amplification).

At regional scales, most of cases analysed here show proportional responses (10 out of 11 cases, Figure 1b). This is assuming an average response considered over the entire regions of interest, masking small-scale spatial heterogeneity in the trophic response; see for instance the case of Black Sea (Figure 4d) which exhibits two contrasting responses within a relatively small basin area (positive amplification in the northern basin, most pronounced in the regions adjacent to the Crimean Peninsula and negative amplification in the southwest near the Bosphorus). This highlights the importance of high-resolution, spatially explicit model analysis. 
An exception to the proportional response at the regional level is found in the Barents Sea (Figure 1b) where an increase in zooplankton biomass and a negative change in phytoplankton biomass are projected. This is interpreted as top-down control due to increased grazing pressure. This is explained because net primary production changes positively and high spatial variation is found in this region. In a future climate, the retreat of sea ice in the Barents Sea changes the seasonality due to light changes. In the present day climate, sea ice is at a minimum only in September for the Arctic Ocean and in the Barents Sea. In the Northern part of the Barents Sea, present day production is therefore strongly light limited. The short seasonal cycle has under present climate conditions therefore also strong implications for the zooplankton potential to utilize the existing particulate organic material due to low prey density. The increase in light extends the seasonal production cycle significantly and supports the second trophic level compared to the first trophic level, which consequently experience a top-down control towards the end of the production season. A relatively important food web restructuring in the Barents Sea is also suggested by the 2.6 times increase in the zooplankton to phytoplankton biomass ratio (Z:P) (from 0.05 to 0.13 ), whilst slight or negligible changes in Z:P ratios are found in most of cases (Table 2). This process might be particular of the Barents Sea since no other region analysed is under the influence of sea ice late in the growing season. A similar, although a much smaller effect, is modelled also in the Bothnian Sea (Baltic Sea). On a basin scale, however, this change is overridden by more pronounced changes in the only occasionally ice covered Central Baltic. Moreover, the modelled sea ice decrease in the Baltic has a smaller impact on the seasonality of the production cycle since it occurred earlier in the year.

\section{Model and projection uncertainty}


The validation of present day models with observations estimates model uncertainty, and the comparison of projections using different models aimed to evaluate projections. One major source of model uncertainty is the bias in the IPSL-CM4 model atmospheric forcing, partially due to the spatial resolution of the IPSL forcing which is too low compared to the spatial resolution of regional case studies. In the Barents Sea region, for instance, sea ice cover in the present day reference simulation is more extensive than observations reveal. In the Benguela upwelling system, wind downscaling (following Goubanova et al., 2011 and Echevin et al., 2012) was also necessary to correct SST seasonality, mixed layer depth, and to provide a better circulation over the domain and more realistic subsurface biogeochemical properties. Each region has been modelled independently and the present day simulation has been validated using present day data specific to the region, i.e. the skill attributed to each regional simulation is different (Table 1). On the other hand, ocean climatology performed better than phytoplankton component in average (Table 1), probably because of error propagation. Moreover, zooplankton has been less scarcely validated than phytoplankton. Thus, the use of those model projections to extend these considerations to higher trophic levels is subjected to high uncertainty. Another limitation of our approach is that we used only one Earth system model and forced by one GHG scenario. For instance, multi-model comparisons at global (Steinacher et al., 2010, and Bopp et al., 2013) and regional (Holt et al., 2014) scales have shown that there are regions of general agreement between models in terms of primary production, with other regions of different signs of changes. Hence, because no estimate of likelihood is available to this study, these results need to be considered as a single selfconsistent response of the system to possible future conditions rather than a prediction with quantified uncertainties. 
To assess projection uncertainty we compared case studies performed within the same area using different models (see Table 1). For climate change modelling, it is generally accepted that averaging of results from an ensemble of models produces a more reliable result (e.g. Pierce et al., 2009), although here only a single model was used in most of the regions. For the North Sea, ECOSMO and POLCOMS-ERSEM models provided similar projections, both suggesting a decrease in primary production (12\% and 3\%, respectively) and in zooplankton biomass (20\% and 7\%, respectively). For the Bay of Biscay, results obtained with ROMSNPZD model in terms of sea warming $\left(+3.49^{\circ} \mathrm{C}\right)$ are in agreement with those obtained with POLCOMS-ERSEM $\left(+2.22{ }^{\circ} \mathrm{C}\right.$; Holt et al., 2012) and previous work using model ensembles (1.5 to $2.1{ }^{\circ} \mathrm{C}$, Chust et al., 2011), although they present slight discrepancies for zooplankton biomass net balance (44\% increase for ROMS-NPZD model and not significant change for POLCOMS-ERSEM). The open question remains how much of these differences can be attributed to the different hydrodynamic models and domains and how much can be attributed to the biogeochemical model structure? In terms of the hydrodynamics, the differences found imply significant differences in nutrient supply to the mixed layer which, in turn, implies difference in the vertical mixing. The finer spatial resolution $(6.5 \mathrm{~km})$ of the ROMS model compared to that of the POLCOMS model $(12 \mathrm{~km})$ might partially explain the biomass differences found, especially in the vicinity of the shelf break. The two models, however, also differ in C:N ratios (fixed in NPZD and variable in ERSEM), and other model properties (ERSEM takes into account explicit microbial loop and benthic component of suspension feeders, whilst NPZD does not) (Table 1). Another important difference that might also explain model projections is the division of plankton groups: ERSEM are represented by four phytoplankton groups (picoplankton, dinoflagellates, flagellates, diatoms) and three zooplankton groups (heterotrophic nanoflagellates, microzooplankton, and mesozooplankton), whilst NPZD consider two size classes for phytoplankton (flagellates and diatoms) and for 
zooplankton (ciliates, copepods); hence, with different links between phytoplankton and zooplankton compartments.

\section{Implications for the biological pump}

In summary, our findings indicate increased ocean stratification by global warming will triggers an overall decrease in zooplankton biomass, which is more pronounced than phytoplankton biomass decrease. This suggests a potential amplification of climate changedriven modifications of trophic level biomass through a bottom-up control, and triggers a slight re-structuring of the food web by decreasing the zooplankton to phytoplankton biomass trophic ratio. Thus, by decreasing the transfer of $\mathrm{CO}_{2}$ fixed by photosynthesis to the deep ocean, the capacity of oceans to regulate the climate via the biological pump will be slightly reduced (Reid et al., 2009) on average but will differ regionally. The overall negative amplification is the most dominant over the global ocean (occupying $47 \%$ of the total area) and it is predominantly found in the tropical oceans; whilst positive amplification of trophic levels prevails in the Arctic and Antarctic oceans where the efficiency of the biological pump might increase. Trophic attenuation is found on average in temperate seas between the amplification regions. On the other hand, the alteration of the seawater carbonate equilibrium, decreasing $\mathrm{pH}$, by the future high levels of $\mathrm{CO}_{2}$ might change the rates of biological carbon consumption and affect calcifying organisms differently (Riebesell et al., 2007), aspects that the global model has not taken into account. The change in the biological carbon pump efficiency would lead to changes in the extent of the deep ocean oxygen minimum zones (Riebesell et al., 2007; Keeling et al., 2010), expanding in the polar regions and reducing in the tropical areas, with possible consequences for marine biogeochemical cycling. On the other side, the uncertainties in projections in ocean productivity imply the need for caution 
when extending these considerations into higher trophic levels. Further research focusing on the response of the oceanic plankton biomass and production to climate change with multimodels estimates at both global and regional scales might reduce these uncertainties. 


\section{Acknowledgements}

This research was funded by the European Commission (Contract No. 212085, MEECE: Marine Ecosystem Evolution in a Changing Environment, and Contract No. 264933, EUROBASIN: European Union Basin-scale Analysis, Synthesis and Integration). We also thank the three anonymous reviewers for their careful assessment of our manuscript. This is contribution 665 from AZTI-Tecnalia Marine Research Division. 


\section{References}

Arthun M, Schrum C (2010) Ocean surface heat flux variability in the Barents Sea. Journal of Marine Systems, 83,88-98.

Arthun M, Ingvaldsen RB, Smedsrud LH, Schrum C (2011) Dense water formation and circulation in the Barents Sea. Deep-Sea Research Part I, 58, 801-817.

Arthun M, Bellerby RGJ, Omar AM, Schrum C (2012) Spatiotemporal variability of air-sea $\mathrm{CO} 2$ fluxes in the Barents Sea, as determined from empirical relationships and modeled hydrography. Journal of Marine Systems, 98-99, 40-50.

Allen, J. I., Aiken, J., Anderson, T. R., Buitenhuis, E., Cornell, S., Geider, R., Haines, K., Hirata, T., Holt, J., Le Quéré, C., Hardman-Mountford, N., Ross, O. N., Sinha, B., and While, 2010. J.: Marine ecosystem models for earth systems applications: The MarQUEST experience, J. Marine Syst., 81, 19-33.

Aumont O, Bopp L (2006) Globalizing results from ocean in situ iron fertilization studies. Global Biogeochemical Cycles, 20, GB2017.

Aumont, O., Bopp, L. \& Schultz, M. (2008) What does temporal variability in aeolian dust deposition contribute to sea-surface iron and chlorophyll distributions? Geophys. Res. Lett, 35, L07607, doi:10.1029/2007GL031131.

Beaugrand, G., Edwards, M., Brander, K., Luczak, C. \& Ibanez, F. (2008) Causes and projections of abrupt climate-driven ecosystem shifts in the North Atlantic. Ecology Letters, 11, 1157-1168.

Behrenfeld, M. J., O'Malley, R. T., Siegel, D. A., McClain, C. R., Sarmiento, J. L., Feldman, G. C., Milligan, A. J., et al. (2006) Climate-driven trends in contemporary ocean productivity. Nature, $444,752-755$. 
Blackford, J. C., Allen, J. I., and Gilbert, F. J. (2004) Ecosystem dynamics at six contrasting sites: a generic model study, J. Marine Syst., 52, 191-215.

Blumberg, A. F. and G. L. Mellor (1987) A description of a three dimensional coastal ocean model, in Three dimensional coastal ocean models, Ed. N. Heaps, A.G.U., Washington. pp. 1-16.

Bopp L, Monfray P, Aumont O et al. (2001) Potential impact of climate change on marine export production. Global Biogeochemical Cycles, 15, 81-99.

Bopp L, Resplandy L, Orr JC et al. (2013) Multiple stressors of ocean ecosystems in the 21st century: projections with CMIP5 models. Biogeosciences, 10, 6225-6245.

Carr, M. and Kearns, E. J. (2003) Production regimes in four Eastern Boundary Current systems, Deep Sea Res. Pt II, 50, 3199-3221, doi:10.1016/j.dsr2.2003.07.015.

Chavez, F. P. and Messié, M. (2009) A comparison of Eastern Boundary Upwelling Ecosystems, Prog. Oceanogr., 83, 80-96, doi:10.1016/j.pocean.2009.07.032.

Cheung WWL, Sarmiento JL, Dunne J et al. (2013) Shrinking of fishes exacerbates impacts of global ocean changes on marine ecosystems. Nature Clim. Change, 3, 254-258.

Cheung, W. W. L., Lam, V. W. Y., Sarmiento, J. L., Kearney, K., Watson, R. E. G., Zeller, D., and Pauly, D. (2010) Large-scale redistribution of maximum fisheries catch potential in the global ocean under climate change. Global Change Biology, 16, 24-35.

Chust G, Borja A, Caballero A, Liria P, Marcos M, Moncho R, Irigoien X, Saenz J, Hidalgo J, Valle M, Valencia V. (2011) Climate Change impacts on the coastal and pelagic environments in the southeastern Bay of Biscay. Climate Research, 48, 307-332.

Collins M, Knutti R, Arblaster JM et al. (2013) Chapter 12: Long-term Climate Change: Projections, Commitments and Irreversibility. In: Working Group I Contribution to the IPCC Fifth Assessment Report (AR5), Climate Change 2013: The Physical Science Basis. 
Cozzi, S. and Giani, M. (2011) River water and nutrient discharges in the northern Adriatic Sea: Current importance and long term changes. Continental Shelf Research, 31, 18811893.

Cury, P.M., Shin, Y.-J.,Planque, B.,Durant, J.M., Fromentin, J.-M., Kramer-Schadt, S., Stenseth, N.C., Travers, M., Grimm, V. (2008) Ecosystem Oceanography for global change in fisheries. Trends in Ecology and Evolution, 23, 338-346.

Daewel, U. and Schrum, C. (2013) Simulating long-term dynamics of the coupled North and Baltic Sea ecosystem with ECOSMO II: model description and validation. Journal of Marine Systems. http://dx.doi.org/10.1016/j.bbr.2011.03.031.

Debreu, L., Marchesiello, P., Penven, P. and Cambon, G. (2012) Two-way nesting in splitexplicit ocean models: algorithms, implementation and validation, Ocean Model., doi: 10.1016 /j.ocemod. 2012.03.003.

Degobbis D., Gilmartin, M. (1990) Nitrogen, Phosphorus and biogenic Silicon budgets for the northern Adriatic Sea. Oceanologica Acta, 13, 31-45.

Dutkiewicz S, Scott JR, Follows MJ (2013) Winners and losers: Ecological and biogeochemical changes in a warming ocean. Global Biogeochemical Cycles, 27, 463-477.

Echevin V, Goubanova K, Belmadani A, Dewitte B (2012) Sensitivity of the Humboldt Current system to global warming: a downscaling experiment of the IPSL-CM4 model. Climate Dynamics, 38, 761-774.

Falkowski PG, Barber RT, Smetacek V (1998) Biogeochemical Controls and Feedbacks on Ocean Primary Production. Science, 281, 200-206.

Fasham MJR, Sarmiento JL, Slater RD, Ducklow HW, Williams R (1993) Ecosystem behavior at Bermuda Station "S" and ocean weather station "India": A general circulation model and observational analysis. Global Biogeochemical Cycles, 7, 379-415. 
Follows MJ, Dutkiewicz S, Grant S, Chisholm SW (2007) Emergent biogeography of microbial communities in a model ocean. Science, 315, 1843-1846.

Forcada, J., Trathan, P. N., Reid, K., Murphy, E. J., and Croxall, J. P. (2006) Contrasting population changes in sympatric penguin species in association with climate warming. Global Change Biology, 12, 411-423.

Franks, P.J.S. (2002) NPZ models of plankton dynamics: their construction, coupling to physics and application. Journal of Oceanography, 58, 379-387.

Good, S.A., Corlett, G.K., Remedios, J.J., Noyes, E.J., Lleweelyn-Jones, D.T. (2007) The global trend in sea surface temperature from 20 years of Advanced Very High Resolution radiometer data. Journal of Climate, 20, 1255-1264.

Goubanova, K., V. Echevin, B. Dewitte, F. Codron, K. Takahashi, P. Terray, M. Vrac (2011) Statistical downscaling of sea-surface wind over the Peru-Chile upwelling region: diagnosing the impact of climate change from the IPSL-CM4 model. Clim. Dyn., 36, 13651378, DOI 10.1007/s00382-010-0824-0.

Gutknecht, E., Dadou, I., Le Vu B., Cambon G., Sudre J., Garçon V., E. Machu E., Rixen T., Kock A., Flohr A., Paulmier A., and Lavik G. (2013a) Coupled physical/biogeochemical modeling including O2-dependent processes in the Eastern Boundary Upwelling Systems: application in the Benguela, Biogeosciences, 10, 3559-3591, doi:10.5194/bg-10-35592013.

Gutknecht, E., Dadou, I., Marchesiello, P., Cambon, G., Le Vu, B., Sudre, J., Garçon, V., Machu, E., Rixen, T., Kock, A., Flohr, A., Paulmier, A., and Lavik, G. 2013b: Nitrogen transfers and sea-air N2O fluxes off Walvis bay: a 3-D model approach in the upwelling off Namibia within the oxygen minimum zone, Biogeosciences, 10, 1-19, doi:10.5194/bg10-1-2013. 
Halpern BS, Longo C, Hardy D et al. (2012) An index to assess the health and benefits of the global ocean. Nature, 488, 615-620.

Hansson L-A, Nicolle A, Graneli W, Hallgren P, Kritzberg E, Persson A, et al. (2013) Foodchain length alters community responses to global change in aquatic systems. Nature Clim Change, 3, 228-233.

Henson S.A., J. L. Sarmiento1, J. P. Dunne, L. Bopp, I. Lima, S. C. Doney, J. John, and C. Beaulieu (2010) Is global warming already changing ocean productivity?, Biogeosciences, 7, 621-640.

Holt, J., Wakelin, S., Lowe, J., and Tinker, J. (2010) The potential impacts of climate change on the hydrography of the northwest European continental shelf. Progress in Oceanography, 86, 361-379.

Holt, J., Butenschön, M., Wakelin, S. L., Artioli, Y., and Allen, J. I. (2012) Oceanic controls on the primary production of the northwest European continental shelf: model experiments under recent past conditions and a potential future scenario, Biogeosciences, 9, 97-117.

Holt, J. T. and James, I. D. (2001) An s-coordinate density evolving model of the North West European Continental Shelf - Part 1: Model description and density structure, J. Geophys. Res., 106, 1401514034, 2001.

Holt, J., Hughes, S., Hopkins, J., Wakelin, S.L., Holliday, N.P., Dye, S., González-Pola, C., Hjøllo, S.S., Mork, K.A., Nolan, G., Proctor, R., Read, J., Shammon, T., Sherwin, T., Smyth, T., Tattersall, G., Ward, B., Wiltshire, K.H. (2012) Multi-decadal variability and trends in the temperature of the northwest European continental shelf: A model-data synthesis. Progress in Oceanography, 106, 96-117.

Holt J, Schrum C, Cannaby H et al. (2014) Physical processes mediating climate change impacts on regional sea ecosystems. Biogeosciences Discuss., 11, 1909-1975. 
IPCC AR4 (2007) Climate Change 2007. The Physical Science Basis. Summary for Policymakers. In: Contribution of Working Group I to the Fourth Assessment Report of the Intergovernmental Panel on Climate Change. Eds. R. Alley, T. Berntsen, N.L. Bindoff et al.

Jochum, M., Schneider, F. D., Crowe, T. P., Brose, U., and O'Gorman, E. J. (2012) Climateinduced changes in bottom-up and top-down processes independently alter a marine ecosystem. Philosophical Transactions of the Royal Society B: Biological Sciences, 367, 2962-2970.

Keeling, R. F., Körtzinger, A., and Gruber, N. (2010) Ocean deoxygenation in a warming world. Annu. Rev. Mar. Sci., 2, 199-229. DOI:10.1146/annurev.marine.010908.163855.

Kirby, R. R., and Beaugrand, G. (2009) Trophic amplification of climate warming. Proceedings of the Royal Society B: Biological Sciences, 276, 4095-4103.

Kirby R, Beaugrand G, Lindley J (2009) Synergistic Effects of Climate and Fishing in a Marine Ecosystem. Ecosystems, 12, 548-561.

Lindley, J. A., Beaugrand, G., Luczak, C., Dewarumez, J. M., and Kirby, R. R. (2010) Warmwater decapods and the trophic amplification of climate in the North Sea. Biology Letters, 6, 773-776.

Ludwig, W., Dumont. E., Meybeck, M., Heussner, S. (2009) River discharges of water and nutrients to the Mediterranean and Black Sea: Major drivers for ecosystem changes during past and future decades? Progress in Oceanography, 80, 199-217.

Ludwig W, Bouwman AF, Dumont E, Lespinas F (2010) Water and nutrient fluxes from major Mediterranean and Black Sea rivers: Past and future trends and their implications for the basin-scale budgets. Global Biogeochemical Cycles, 24, GB0A13. 
Madec, G. (2008) NEMO reference manual, ocean dynamic component: NEMO-OPA. Note du Pole de modelisation, Institut Pierre Simon Laplace, Technical Report 27, ISSN No, 1288-1619.

MEECE report (2013). Deliverable D3.4 Synthesis report on climate simulations. Baltic Sea: http://www.meece.eu/documents/deliverables/WP3/D3\%204_Part4_Baltic.pdf Barents Sea: http://www.meece.eu/documents/deliverables/WP3/D3\%204_Part2_Barents.pdf. Black Sea: http://www.meece.eu/documents/deliverables/WP3/D3\%204_Part5_BlackSea.pdf Bay of Biscay: http://www.meece.eu/documents/deliverables/WP3/D3\%204_Part6_Biscay.pdf Adriatic Sea: http://www.meece.eu/documents/deliverables/WP3/D3\%204_Part7_Adriatic.pdf NE Atlantic and North Sea: http://www.meece.eu/documents/deliverables/WP3/D3\%204_Part3_NE\%20Atlantic.pdf North Aegean Sea: http://www.meece.eu/documents/deliverables/WP3/D3\%204_Part8_Aegean.pdf Benguela Upwelling: http://www.meece.eu/documents/deliverables/WP3/D3\%204_Part9_Benguela.pdf

Mozetič, P., Solidoro, C., Cossarini, G., \& Socal, G., Precali, R. Francé, J., Bianchi, F., De Vittor, C., Smodlaka, N, S. Fonda Umani (2009) Recent Trends Towards Oligotrophication of the Northern Adriatic: Evidence from Chlorophyll a Time Series. Estuaries and Coasts, 33, 362-375. DOI: 10.1007/s12237-009-9191-7.

Nakicenovic, N., Swart, R. (2000) Special Report on Emissions Scenarios. A Special Report of Working Group III of the Intergovernmental Panel on Climate Change. Cambridge University Press, Cambridge, UK and New York, NY, USA, p. 599 pp.

Oguz, T., Ducklow, H.W., Purcell, J.E., Malanotte-Rizzoli, P. (2001b) Modeling the response of top-down control exerted by gelatinous carnivores on the Black Sea pelagic foodweb. J. Geophys. Res. 106, 4543-4564.

Pauly D, Christensen V, Dalsgaard J, Froese R, Torres F Jr. (1998) Fishing down marine food webs. Science, 279, 860-3.

Penven, P., Debreu, L., Marchesiello, P. and McWilliams, J. C. (2006a) Evaluation and application of the ROMS 1-way embedding procedure to the central California upwelling system, Ocean Model., 12, 157-187, doi:10.1016/j.ocemod.2005.05.002.

Petihakis G, Triantafyllou G, Allen JI, Hoteit I, Dounas C (2002) Modelling the spatial and temporal variability of the Cretan Sea ecosystem. Journal of Marine Systems, 36, 173-196. 
Philippart CJM, Anadón R, Danovaro R, Dippner JW, Drinkwater KF, Hawkins SJ, Oguz T, O'Sullivan G, Reid PC (2011) Impacts of climate change on European marine ecosystems: Observations, expectations and indicators. J Exp Mar Biol Ecol, 400, 52-69

Pierce, D.W., Barnett, T.P., Santer, B.D., Gleckler, P.J. (2009) Selecting global climate models for regional climate change studies. Proc. Natl. Acad. Sci., 106, 8441-8446.

Reid, P.C., Fischer, A.C., Lewis-Brown, E., Meredith, M.P., Sparrow, M., Andersson, A.J., Antia, A., Bates, N.R., Bathmann, U., Beaugrand, G., Brix, H., Dye, S., Edwards, M., Furevik, T., Gangsto, R., Hatun, H., Hopcroft, R.R., Kendall, M., Kasten, S., Keeling, R., Le Quere, C., Mackenzie, F.T., Malin, G., Mauritzen, C., Olafsson, J., Paull, C., Rignot, E., Shimada, K., Vogt, M., Wallace, C., Wang, Z. \& Washington, R. (2009) Chapter 1. Impacts of the oceans on climate change. Adv Mar Biol, 56, 1-150.

Rhein M, Rintoul SR, Aoki S et al. (2013) Chapter 3: Observations: Ocean In: Working Group I Contribution to the IPCC Fifth Assessment Report (AR5), Climate Change 2013: The Physical Science Basis.

Richardson, A. J. (2008) In hot water: zooplankton and climate change. - ICES Journal of Marine Science, 65, 279-295.

Riebesell U, Schulz KG, Bellerby RGJ et al. (2007) Enhanced biological carbon consumption in a high $\mathrm{CO} 2$ ocean. Nature, 450, 545-548.

Rodgers, K.B., Aumont, O., Menkes, C. \& Gorgues, T. (2008) Decadal variations in equatorial Pacific ecosystems and ferrocline/pycnocline decoupling, Global Biogeochemical Cycles, 22, GB2019, doi:10.1029/2006GB002919.

Ruggio R, Vichi M, Paparella F, Masina S (2013) Climatic trends of the equatorial undercurrent: A backup mechanism for sustaining the equatorial Pacific production. Journal of Marine Systems, 121, 11-23. 
Rykaczewski RR, Dunne JP (2010) Enhanced nutrient supply to the California Current Ecosystem with global warming and increased stratification in an earth system model. Geophysical Research Letters, 37, L21606.

Schrum, C. (2001) Regionalization of climate change for the North Sea and the Baltic Sea. Climate Research, 18, 31-37.

Schrum, C., Alekseeva, I., and St.John, M. (2006) Development of a coupled physicalbiological ecosystem model ECOSMO: Part I: Model description and validation for the North Sea. Journal of Marine Systems, 61, 79-99.

Shchepetkin, A. F. and J. C. McWilliams (2005) The regional ocean modeling system (ROMS): A split-explicit, free-surface, topography-following-coordinate oceanic model. Ocean Modeling, 9, 347-404, doi:10.1016/j.ocemod.2004.08.002.

Steinacher M., F. Joos, T. L. Frölicher, L. Bopp, P. Cadule, S. C. Doney, M. Gehlen, B. Schneider, and J. Segschneider (2010) Projected 21st century decrease in marine productivity: a multi-model analysis, Biogeosciences, 7, 979-1005.

Taucher, J., Oschlies, A. (2011) Can we predict the direction of marine primary production change under global warming? Geophysical Research Letters, 38, 6.

Taylor, K. E. (2001) Summarizing multiple aspects of model performance in a single diagram, Journal of Geophysical Research, 106, 7183-7192.

Tsiaras, K., Petihakis G., Kourafalou, V., Triantafyllou G., 2014. Impact of the river nutrient load variability on the N. Aegean ecosystem functioning over the last decades. Journal of Sea Research, 86, 97-109.

Vichi, M., Pinardi, N., Masina S. (2007) A generalized model of pelagic biogeochemistry for the global ocean ecosystem. Part I: Theory. Journal of Marine Systems, 64, 89-109. 
Vichi M, Manzini E, Fogli P et al. (2011) Global and regional ocean carbon uptake and climate change: sensitivity to a substantial mitigation scenario. Climate Dynamics, 37, 1929-1947.

Wang, Y., Leung, L.R., McGregor, J.L., Lee, D.-K., Wang, W.-C., Ding, Y., Kimura, F., (2004) Regional Climate Modeling: Progress, Challenges, and Prospects. J. Meteorol. Soc. Japan, 82, 1599-1628. 
Figure legends

Figure 1. A) Framework of climate change effects on the amplification or attenuation of the trophic levels. B) and C) Projected phytoplankton response (fractional change) to climate change scenarios versus zooplankton response expected by the end of the 21 st century (at 2080-2100 relative to 1980-2000, under A1B Scenario). B) Overall average for each case study; Ad: Adriatic Sea, BB: Bay of Biscay, Gl: Global, Ce: Celtic Sea, No: North Sea, AM: Atlantic Margin, Be: Benguela upwelling system, Ae: Aegean Sea. C) Global grid cells (1:1 indicate proportional change). Positive amplification: 9.1\%, negative amplification: $47.3 \%$, proportional change (taking a threshold of \pm 0.01 ): $11.7 \%$, positive attenuation: $8.8 \%$, negative attenuation: $12.7 \%$, positive top-down: $5.5 \%$, and negative top-down: $5.1 \%$.

Figure 2. Projected plankton response to climate change scenarios expected by the end of the 21 st century (at 2080-2100 relative to 1980-2000). For those study regions analysed with different models, values correspond to mean.

Figure 3. Projected change in lower trophic level response (phytoplankton and zooplankton biomass) to climate change scenarios expected by the end of the 21st century (at 2080-2100 relative to 1980-2000, under A1B Scenario).

Figure 4. Change in net primary production (a), depth integrated phytoplankton (b) and zooplankton biomass (c) at 2080-2100, relative to 1980-2000, within the Black Sea. (d) Trophic propagation according to changes in phytoplankton to zooplankton biomass for the same climate change scenario.

Figure 5. Global change in net primary production (a) and in zooplankton biomass (b) expected by the end of the 21 st century (at 2080-2100 relative to 1980-2000). (c) Trophic propagation according to changes in phytoplankton to zooplankton biomass for the same climate change scenario.

Figure 6. Global (a) phytoplankton biomass across latitudes, and (b) phytoplankton against zooplankton biomass. Data extracted from the NEMO-PISCES model for the present conditions. 


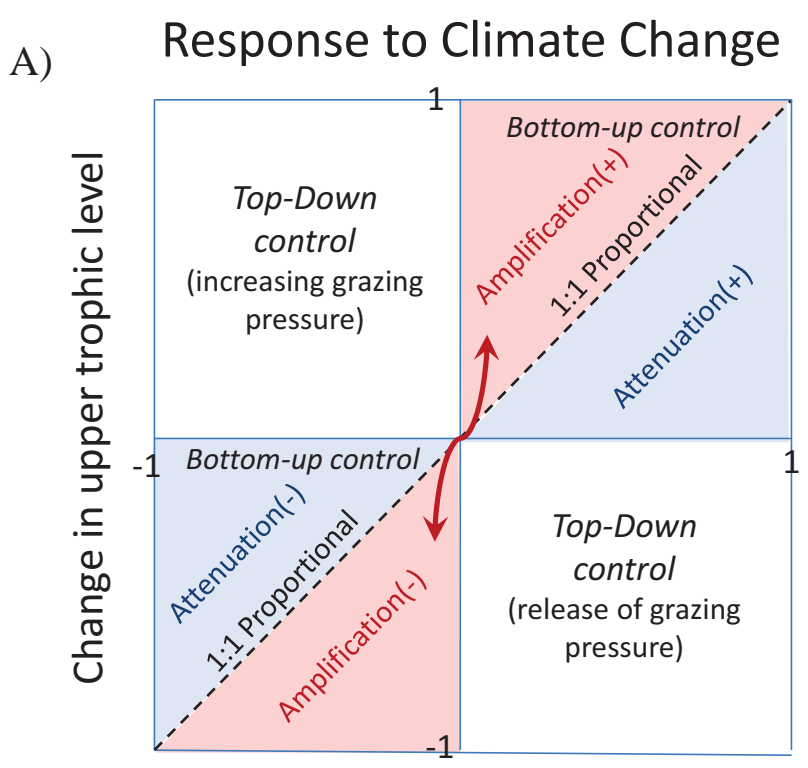

Change in lower trophic level

B)

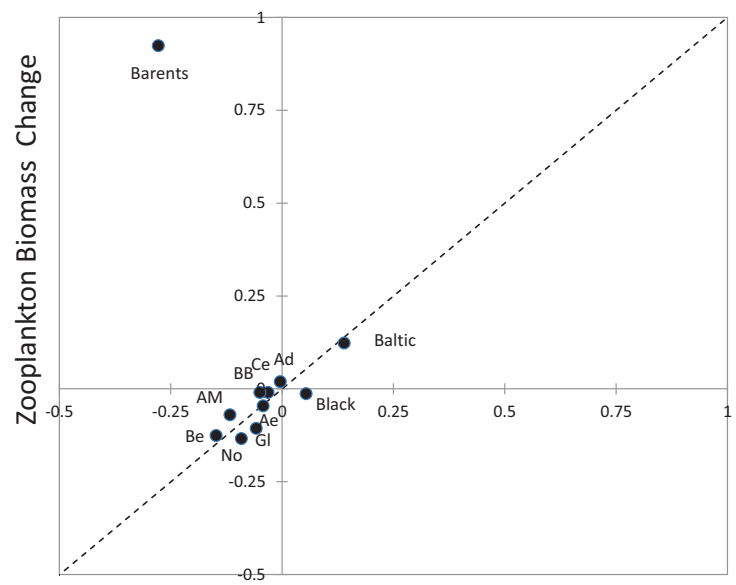

Phytoplankton Biomass Change

C)

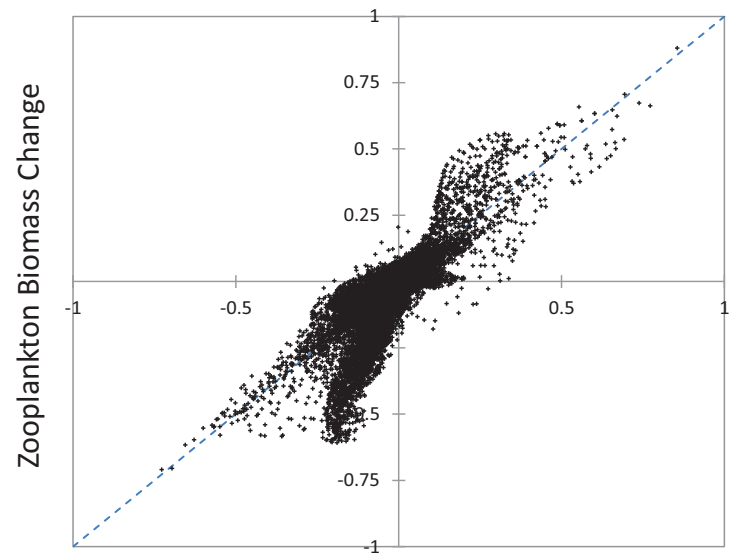

Phytoplankton Biomass Change

Figure 7. 


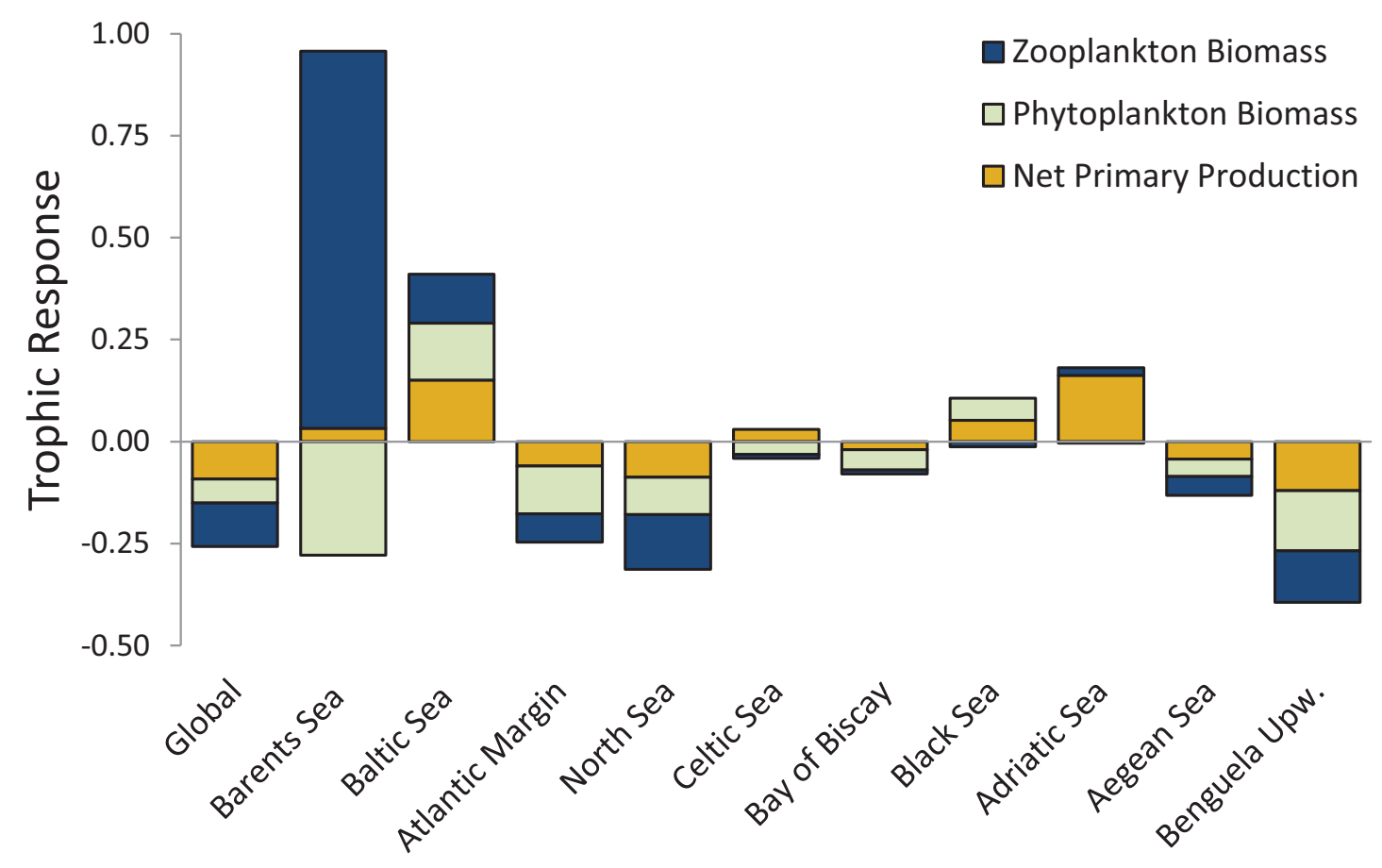

Figure 8. 
Barents Sea
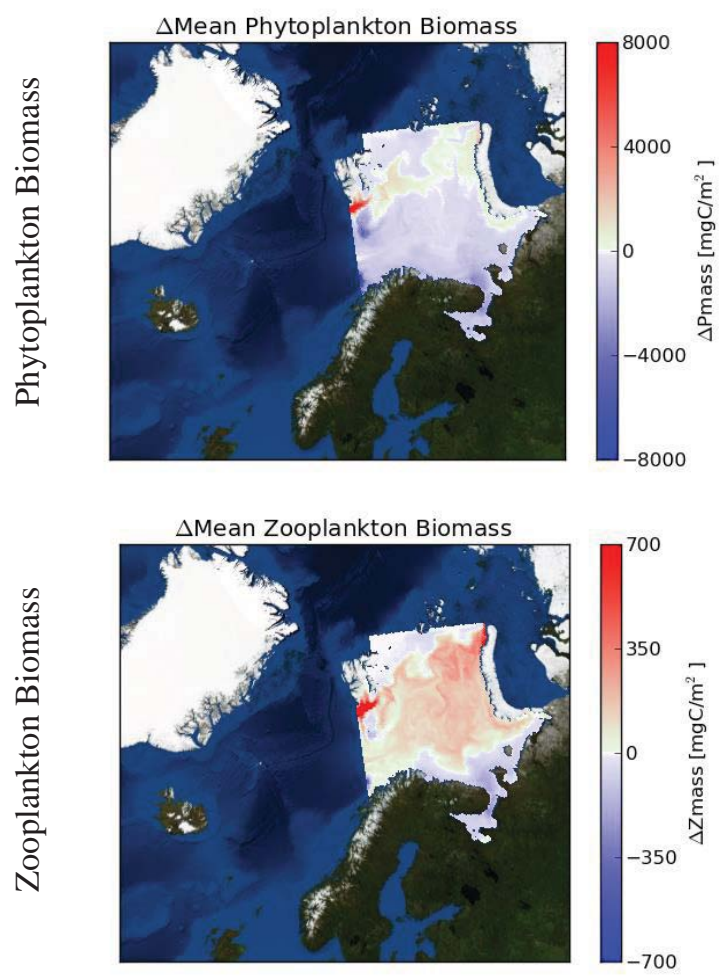

Baltic Sea
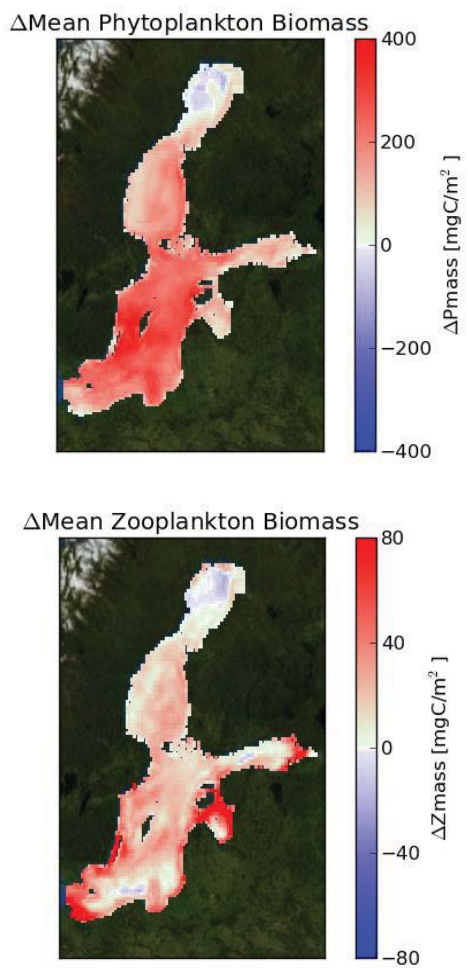

Bay of Biscay
North Sea
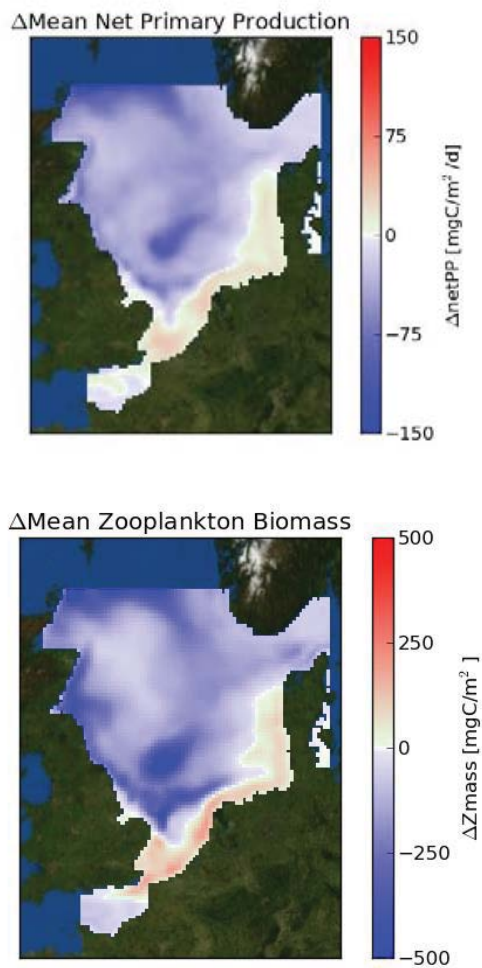

Atlantic Margin
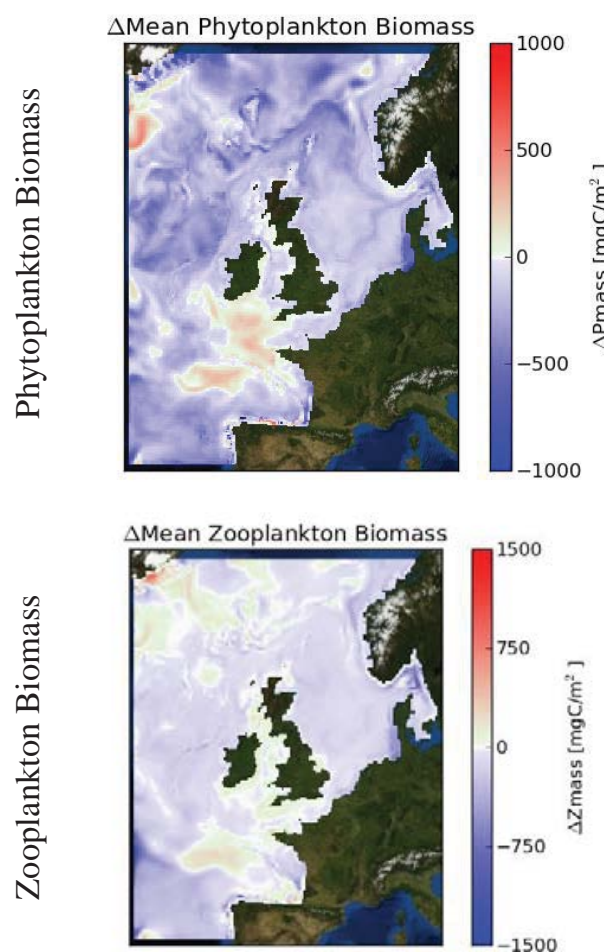
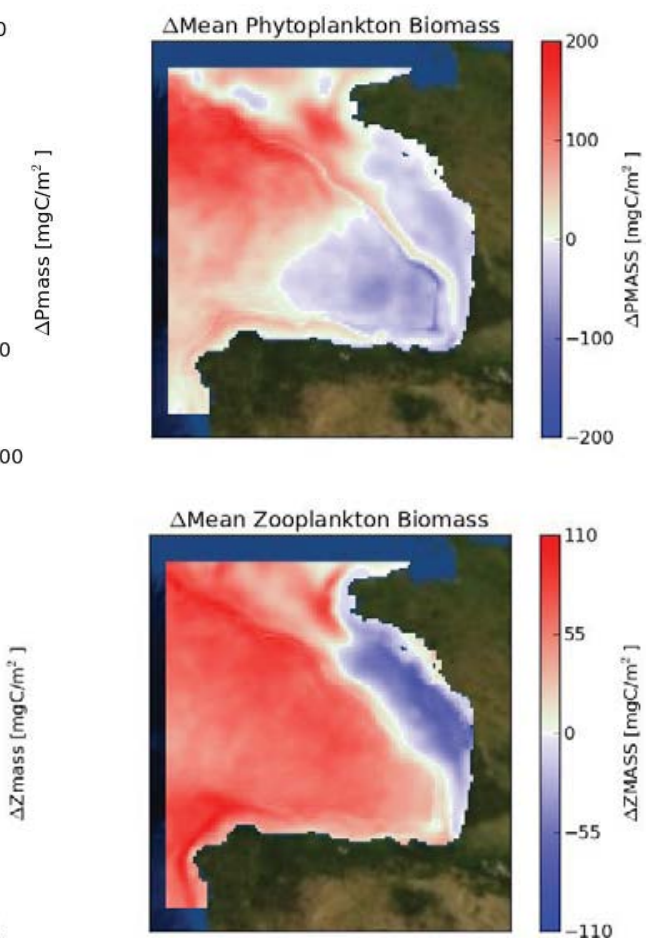

North Aegean Sea
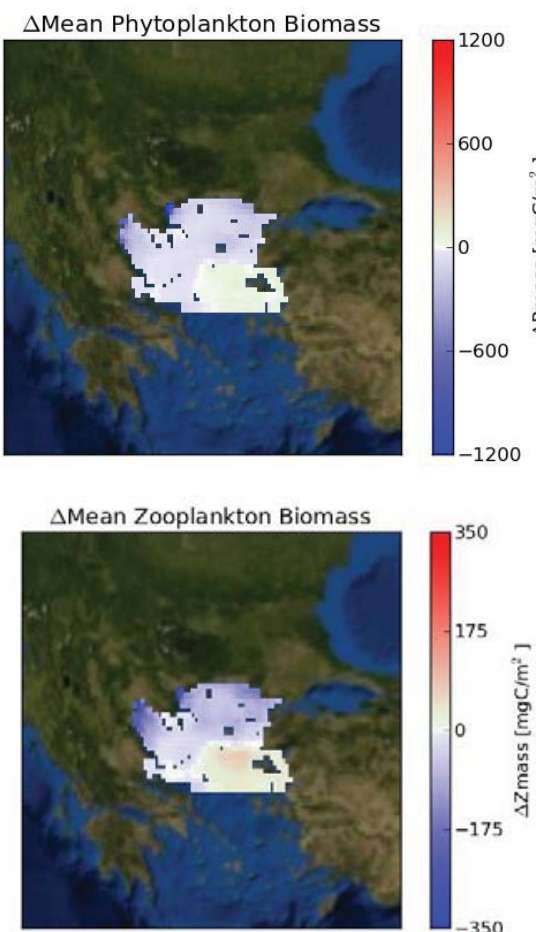
Adriatic Sea
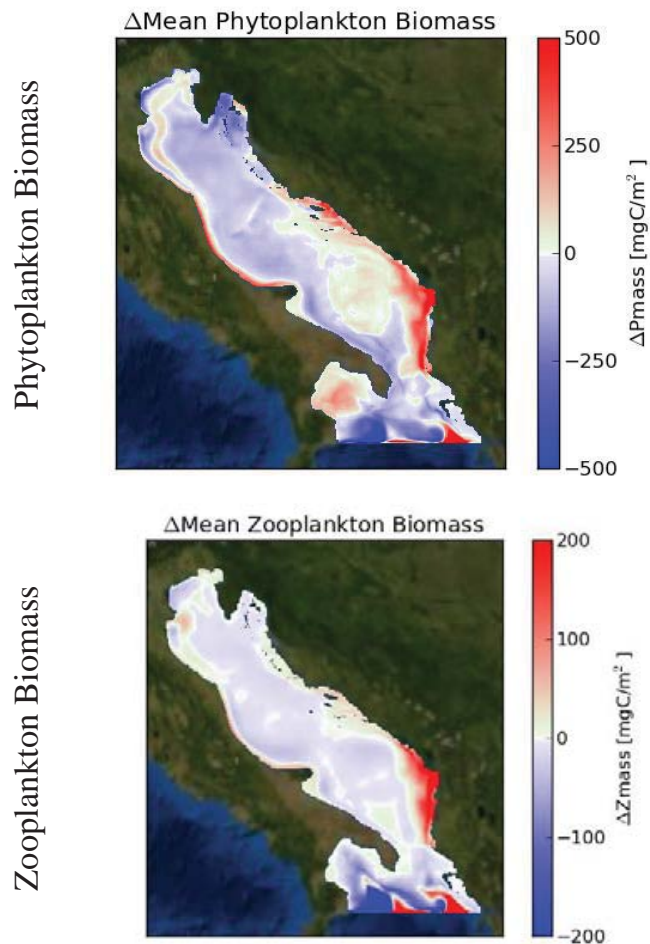

Benguela
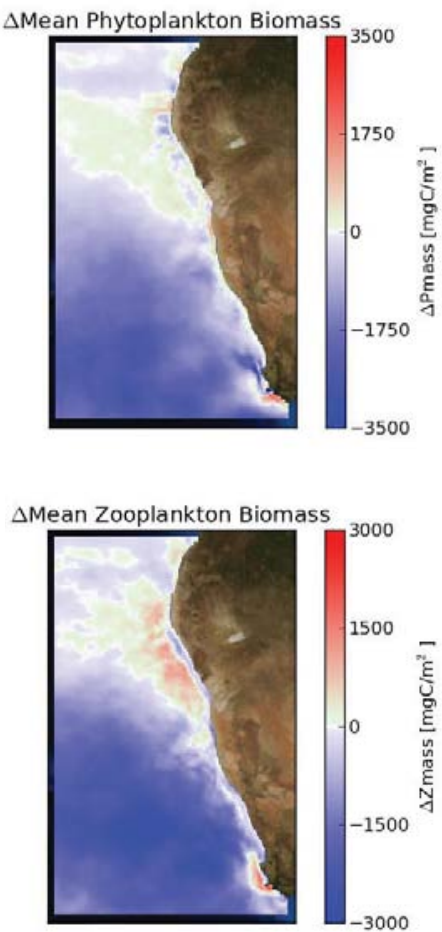

Figure 9. 
Phytoplankton Biomass Change Zooplankton Biomass Change
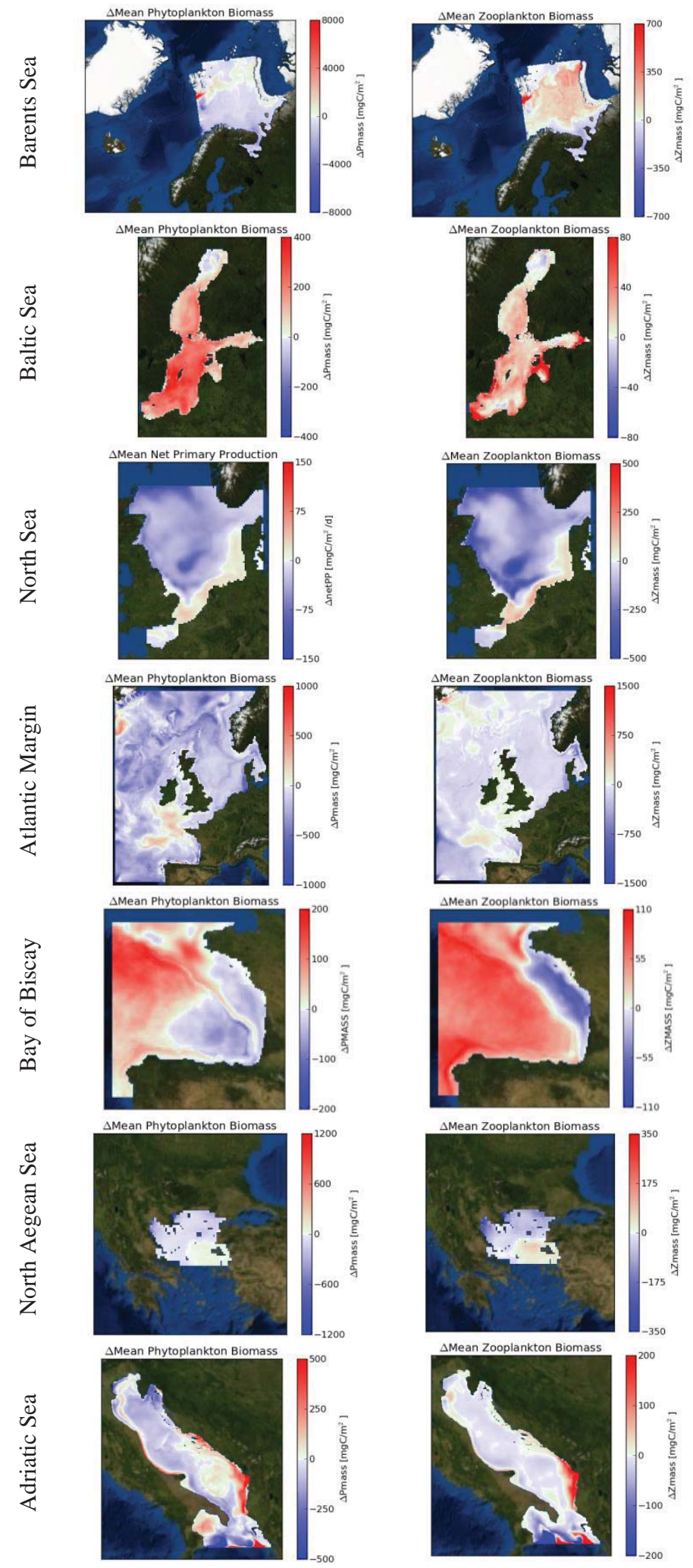

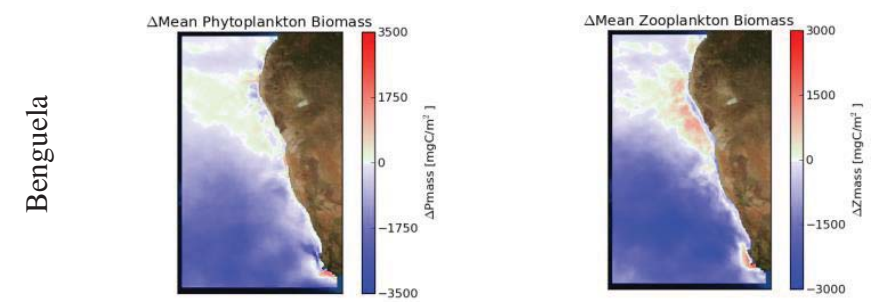

Page 43 

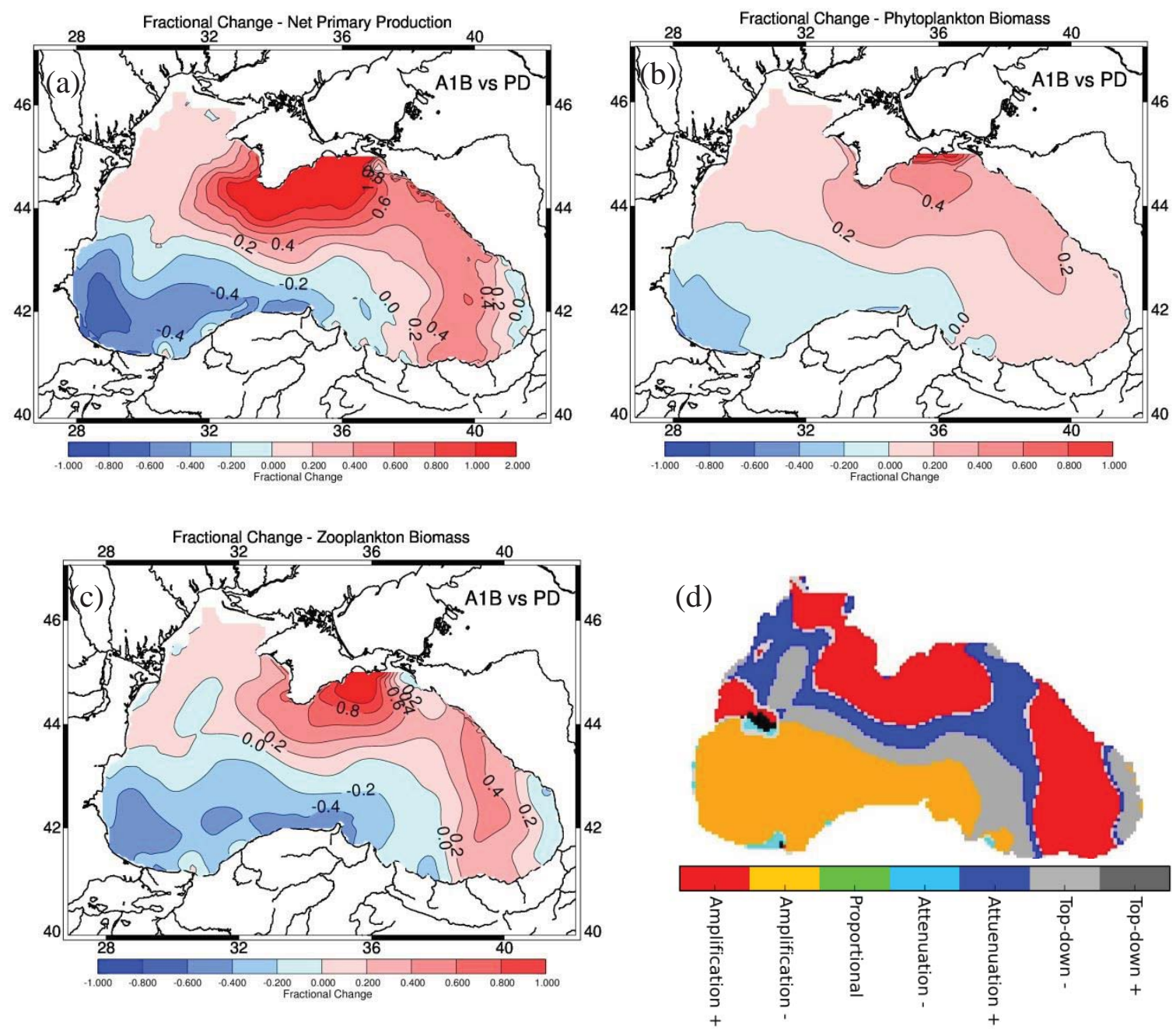

Figure 10. 
(a)

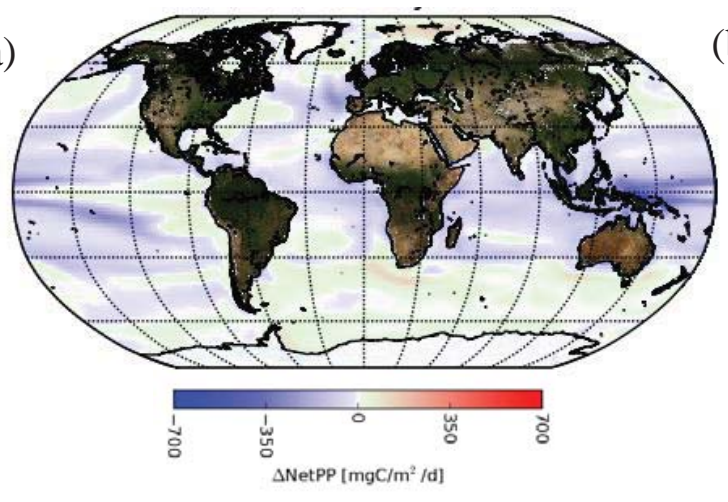

(b)
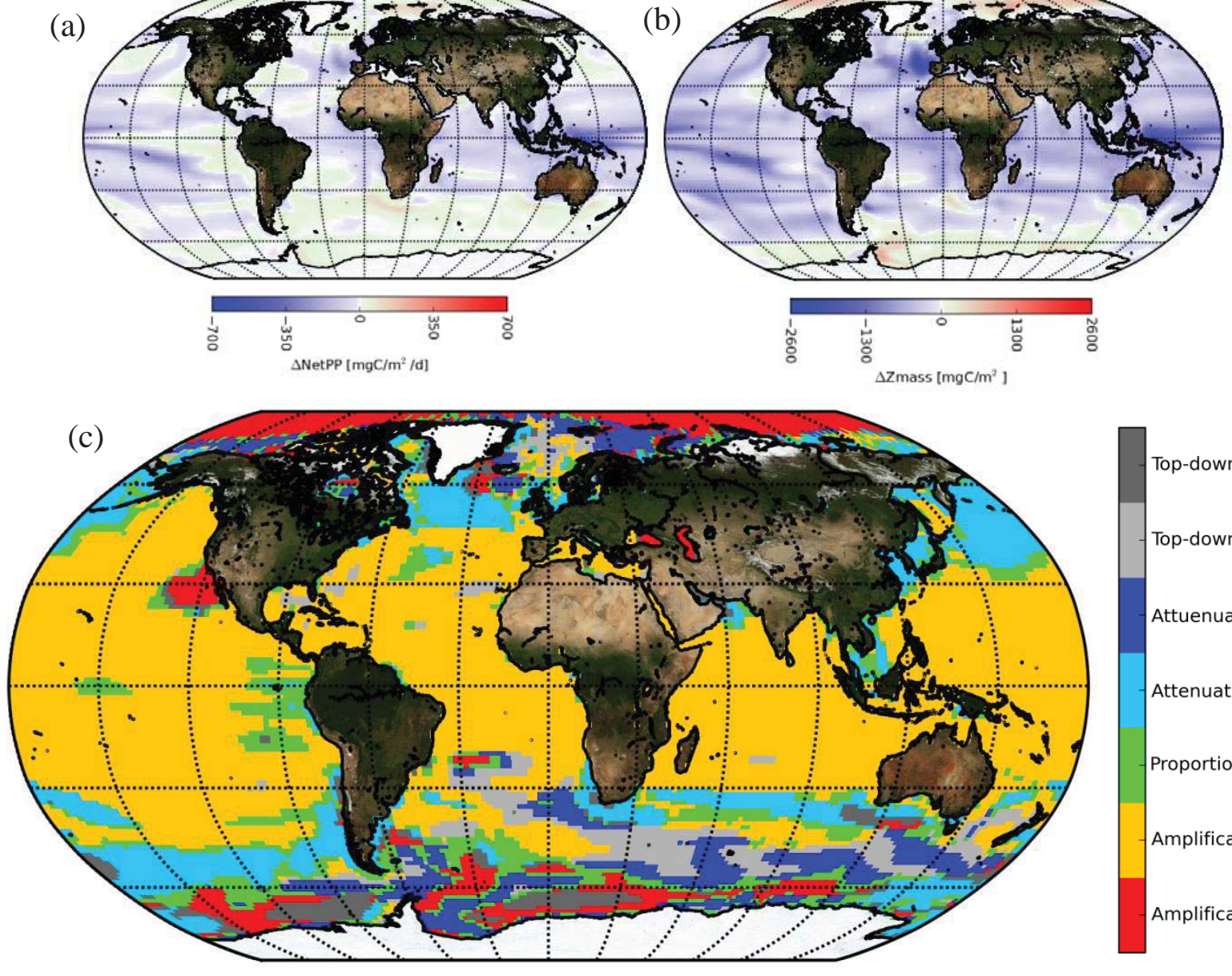

Top-down +

Top-down -

Attuenuation +

Attenuation -

Proportional

Figure 11. 

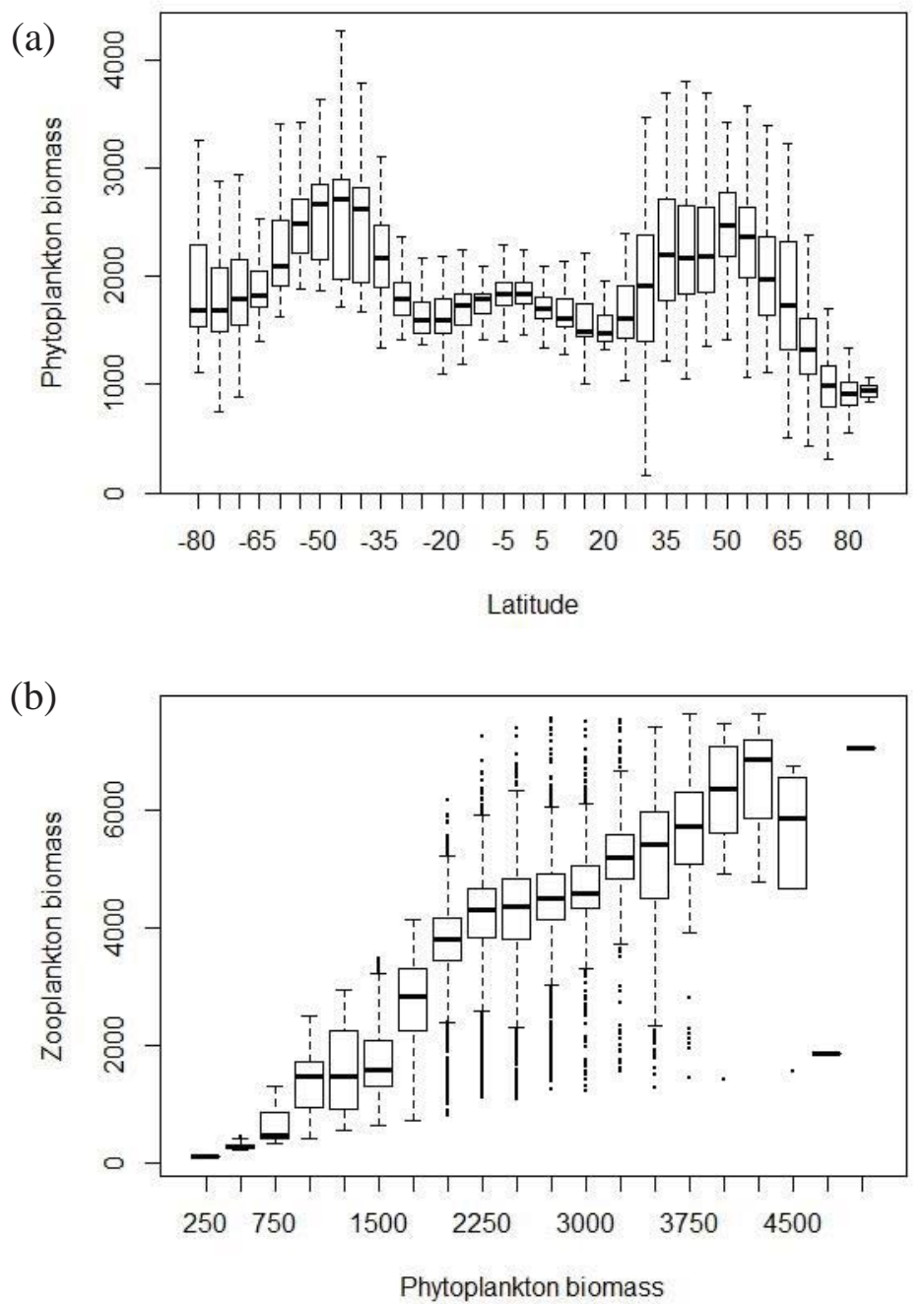

Figure 12. 


\section{TABLES}

Table 1. Coupled physical-biogeochemical models used by each region and the corresponding model properties and hindcast validation assessment ( $r$ : correlation, NSD: Normalised Standard Deviation, bias: average deviation across the region and for all months) for sea surface temperature (SST) and chlorophyll concentration. Satellite data were used for hindcast validation in several regions: AVHRR data for SST (Adriatic Sea, N. Aegean Sea, Bay of Biscay, Black Sea) and SeaWIFS for chlorophyll (Adriatic Sea, N. Aegean Sea, Bay of Biscay, Black Sea). In Benguela, CARS climatologies were used for sea temperature (CARS, 2009: CSIRO Atlas of Regional Seas, http://www.marine.csiro.au/ dunn/cars2009, 03/30/2011). ICES data base (http://www.ices.dk/ocean/aspx/HydChem/HydChem.aspx) was used for sea temperature in the North Atlantic Margin and in the Baltic Sea. In the Barents Sea, a compilation from different sources of sea temperature was undertaken for hindcast validation (see Årthun et al., 2011, 2012 and Årthun \& Schrum, 2010). For model properties (explicit microbial loop (bacteria), temperature $(\mathrm{T})$ dependence rates for phytoplankton growth, and benthic biology), Y: yes, N: not. 


\begin{tabular}{|c|c|c|c|c|c|c|c|c|c|c|c|c|c|c|c|}
\hline \multirow[t]{3}{*}{ Region } & \multirow{3}{*}{$\begin{array}{l}\text { Coupled } \\
\text { physical- } \\
\text { biogeochemical } \\
\text { model }\end{array}$} & \multicolumn{8}{|c|}{ Model properties } & \multicolumn{6}{|c|}{ Hindcast Validation } \\
\hline & & \multirow{2}{*}{$\begin{array}{l}\text { Fixed or } \\
\text { Variable } \\
\text { C:N }\end{array}$} & \multirow{2}{*}{$\begin{array}{l}\text { Phytoplankton } \\
\text { classes }\end{array}$} & \multirow{2}{*}{$\begin{array}{l}\text { Zooplankton } \\
\text { classes }\end{array}$} & \multirow{2}{*}{$\begin{array}{c}\text { Explicit } \\
\text { microbial } \\
\text { loop } \\
\text { (bacteria) } \\
\end{array}$} & \multirow{2}{*}{$\begin{array}{c}T \\
\text { dependence } \\
\text { rates }\end{array}$} & \multirow{2}{*}{$\begin{array}{l}\text { Benthic } \\
\text { Biology }\end{array}$} & \multirow{2}{*}{$\begin{array}{c}\text { Horizontal } \\
\text { resolution }\end{array}$} & \multirow{2}{*}{$\begin{array}{c}\text { Vertical } \\
\text { resolution }\end{array}$} & \multicolumn{3}{|c|}{ SST } & \multicolumn{3}{|c|}{ Chlorophyll } \\
\hline & & & & & & & & & & $r$ & NSD & $\begin{array}{l}\text { Bias } \\
\left({ }^{\circ} \mathrm{C}\right)\end{array}$ & $r$ & NSD & $\begin{array}{c}\text { Bias } \\
\left(\mathrm{mg} / \mathrm{m}^{3}\right)\end{array}$ \\
\hline Global & NEMO-PISCES & F & $\begin{array}{c}\text { Nanophytoplankton } \\
\text { Diatoms }\end{array}$ & $\begin{array}{l}\text { Microzooplankton } \\
\text { Mesozooplankton }\end{array}$ & $\mathrm{N}$ & Y & $\mathrm{N}$ & $\sim 2^{\circ}$ & 30 lev. & 0.96 & 1.0 & & 0.5 & 0.5 & \\
\hline \multirow{2}{*}{$\begin{array}{l}\text { Greater } \\
\text { North Sea }\end{array}$} & $\begin{array}{l}\text { POLCOMS- } \\
\text { ERSEM }\end{array}$ & $\mathrm{V}$ & $\begin{array}{c}\text { Picoplankton } \\
\text { Dinoflagellates } \\
\text { Flagellates } \\
\text { Diatoms }\end{array}$ & $\begin{array}{c}\text { Heterotrophic } \\
\text { nanoflagellates } \\
\text { Microzooplankton } \\
\text { Mesozooplankton }\end{array}$ & Y & Y & Y & $12 \mathrm{~km}$ & $42 \sigma$ lev. & 0.93 & 1.04 & 0.03 & 0.32 & 0.27 & -1.69 \\
\hline & ECOSMO & $\mathrm{F}$ & $\begin{array}{c}\text { Flagellates } \\
\text { Diatoms }\end{array}$ & $\begin{array}{l}\text { Microzooplankton } \\
\text { Macrozooplankton }\end{array}$ & $\mathrm{N}$ & $\mathrm{N}^{*}$ & $\mathrm{~N}$ & $9-11 \mathrm{~km}$ & 20 lev. & $\begin{array}{c}0.79 \\
\text { to } \\
0.98\end{array}$ & $\begin{array}{c}0.8 \\
\text { to } \\
1.1\end{array}$ & & na & na & na \\
\hline $\begin{array}{l}\text { Atlantic } \\
\text { Margin }\end{array}$ & $\begin{array}{l}\text { POLCOMS- } \\
\text { ERSEM }\end{array}$ & $\mathrm{V}$ & $\begin{array}{c}\text { Picoplankton } \\
\text { Dinoflagellates } \\
\text { Flagellates } \\
\text { Diatoms }\end{array}$ & $\begin{array}{c}\text { Heterotrophic } \\
\text { nanoflagellates } \\
\text { Microzooplankton } \\
\text { Mesozooplankton }\end{array}$ & Y & $\mathrm{Y}$ & Y & $12 \mathrm{~km}$ & $42 \sigma$ lev. & 0.93 & 1.09 & $\overline{-} 08$ & 0.28 & 0.31 & -0.96 \\
\hline $\begin{array}{l}\text { Barents } \\
\text { Sea }\end{array}$ & ECOSMO & $\mathrm{F}$ & $\begin{array}{l}\text { Flagellates } \\
\text { Diatoms }\end{array}$ & $\begin{array}{l}\text { Microzooplankton } \\
\text { Macrozooplankton }\end{array}$ & $\mathrm{N}$ & $\mathrm{N}^{*}$ & $\mathrm{~N}$ & $7 \mathrm{~km}$ & 16 lev. & $\begin{array}{c}0.82 \\
\text { to } \\
0.86\end{array}$ & & $\begin{array}{c}0.06 \\
\text { to } \\
0.53\end{array}$ & na & na & na \\
\hline Baltic Sea & ECOSMO & $\mathrm{F}$ & $\begin{array}{c}\text { Flagellates } \\
\text { Diatoms } \\
\text { Cyanobacteria } \\
\end{array}$ & $\begin{array}{l}\text { Microzooplankton } \\
\text { Macrozooplankton }\end{array}$ & $\mathrm{N}$ & $\mathrm{N}^{*}$ & $\mathrm{~N}$ & $9-11 \mathrm{~km}$ & 20 lev. & 0.88 & $\begin{array}{c}0.7 \\
\text { to } \\
1.9 \\
\end{array}$ & & na & na & na \\
\hline Black Sea & $\begin{array}{l}\text { POM-BIMS- } \\
\text { ECO }\end{array}$ & $\mathrm{F}$ & $\begin{array}{c}\text { Small } \\
\text { phytoplankton } \\
\text { Large } \\
\text { phytoplankton }\end{array}$ & $\begin{array}{c}\text { Microzooplankton } \\
\text { Mesozooplankton } \\
\text { Heterotrophic } \\
\text { dinoflagellate } \\
\text { (Noctiluca } \\
\text { scintillans) } \\
\text { Gelatinous } \\
\text { carnivore (Aurelia } \\
\text { aurita) } \\
\text { Gelatinous } \\
\text { carnivore } \\
\text { (Mnemiopsis } \\
\text { leidyi) }\end{array}$ & $\mathrm{N}$ & $\mathrm{Y}$ & $\mathrm{N}$ & $7-8 \mathrm{~km}$ & 23 lev. & 0.95 & 1.4 & $0 . \overline{3}$ & 0.29 & 0.77 & -0.05 \\
\hline \multirow{2}{*}{$\begin{array}{l}\text { Bay of } \\
\text { Biscay }\end{array}$} & $\begin{array}{l}\text { POLCOMS- } \\
\text { ERSEM }\end{array}$ & $\mathrm{V}$ & $\begin{array}{c}\text { Picoplankton } \\
\text { Dinoflagellates } \\
\text { Flagellates } \\
\text { Diatoms }\end{array}$ & $\begin{array}{c}\text { Heterotrophic } \\
\text { nanoflagellates } \\
\text { Microzooplankton } \\
\text { Mesozooplankton }\end{array}$ & $\mathrm{Y}$ & $\mathrm{Y}$ & $\mathrm{Y}$ & $12 \mathrm{~km}$ & $42 \sigma$ lev. & 0.88 & 0.95 & $\begin{array}{c}- \\
0.10\end{array}$ & 0.42 & 0.91 & 0.35 \\
\hline & ROMS-NPZD & $\mathrm{F}$ & $\begin{array}{l}\text { Flagellates } \\
\text { Diatoms }\end{array}$ & $\begin{array}{l}\text { Ciliates } \\
\text { Copepods }\end{array}$ & $\mathrm{N}$ & $\mathrm{Y}$ & $\mathrm{N}$ & $6.5 \mathrm{~km}$ & $32 \sigma$ lev. & $\begin{array}{c}0.8 \\
\text { to } \\
0.9\end{array}$ & $\begin{array}{c}0.75 \\
\text { to } \\
1.25\end{array}$ & & na & na & na \\
\hline $\begin{array}{l}\text { Adriatic } \\
\text { Sea }\end{array}$ & POM-BFM & $\mathrm{v}$ & $\begin{array}{l}\text { Picophytoplankton } \\
\text { Flagellates } \\
\text { Diatoms } \\
\text { Large } \\
\text { phytoplankton }\end{array}$ & $\begin{array}{c}\text { Microzooplankton } \\
\text { Heterotrophic } \\
\text { nanoflagellates } \\
\text { Mesozooplankton } \\
\text { carnivorous } \\
\text { Mesozooplankton } \\
\text { omnivorous } \\
\end{array}$ & $\mathrm{Y}$ & $\mathrm{Y}$ & $\mathrm{N}$ & $2 \mathrm{~km}$ & $24 \sigma$ lev. & $\begin{array}{c}0.94 \\
\text { to } \\
0.97\end{array}$ & $\begin{array}{c}0.9 \\
\text { to } \\
1.2\end{array}$ & $\begin{array}{c}0.35 \\
\text { to } \\
1.8\end{array}$ & $\begin{array}{c}0.5 \\
\text { to } \\
0.6\end{array}$ & $\begin{array}{l}0.21 \\
\text { and } \\
0.58\end{array}$ & $\begin{array}{l}-0.25 \text { to } \\
-0.06\end{array}$ \\
\hline $\begin{array}{l}\text { North } \\
\text { Aegean } \\
\text { Sea }\end{array}$ & POM-ERSEM & $\mathrm{V}$ & $\begin{array}{c}\text { Picoplankton } \\
\text { Dinoflagellates } \\
\text { Flagellates } \\
\text { Diatoms } \\
\end{array}$ & $\begin{array}{c}\text { Heterotrophic } \\
\text { nanoflagellates } \\
\text { Microzooplankton } \\
\text { Mesozooplankton }\end{array}$ & $\mathrm{Y}$ & $\mathrm{Y}$ & Y & $10 \mathrm{~km}$ & $25 \sigma$ lev. & $\begin{array}{c}0.55 \\
\text { to } \\
0.99\end{array}$ & $\begin{array}{c}0.5 \\
\text { to } \\
1.6\end{array}$ & 0.19 & $\begin{array}{c}0.4 \\
\text { to } \\
0.8\end{array}$ & $\begin{array}{c}0.2 \\
\text { to } \\
2.0\end{array}$ & -0.11 \\
\hline $\begin{array}{l}\text { Benguela } \\
\text { Upwelling } \\
\text { System }\end{array}$ & $\begin{array}{l}\text { ROMS-AGRIF- } \\
\text { BIOEBUS }\end{array}$ & $\mathrm{F}$ & $\begin{array}{l}\text { Flagellates } \\
\text { Diatoms }\end{array}$ & $\begin{array}{c}\text { Ciliates } \\
\text { Copepods }\end{array}$ & $\mathrm{N}$ & Y & $\mathrm{N}$ & $7.5-9.2 \mathrm{~km}$ & $32 \sigma$ lev. & 0.99 & 0.95 & & na & na & na \\
\hline
\end{tabular}

* Yes for remineralisation rates. 
Table 2. Projected climate changes and ecosystem responses expected by the end of the $21^{\text {st }}$ century (at 2080-2100 relative to 1980-2000, under A1B Scenario). Legend: For spatial variability, Low: most of areas with same trends, High: some areas with opposite trends with respect to others. Units and legend: SST $\left({ }^{\circ} \mathrm{C}\right)$, netPP: Net Primary Production Depth integrated, Zooplankton (biomass depth integrated), Z:P is the zooplankton to phytoplankton biomass ratio. The phytoplankton and zooplankton biomass changes of the global model corresponding to the regions (two right columns) are omitted in Celtic Sea, Black Sea, Adriatic Sea and Aegean Sea due to their small size in relation to the global model. 


\begin{tabular}{|c|c|c|c|c|c|c|c|c|c|c|}
\hline \multirow{2}{*}{\multicolumn{2}{|c|}{\begin{tabular}{|l|} 
\\
Region
\end{tabular}}} & & \multicolumn{6}{|c|}{ Change range at $2080-2100$ relative to $1980-2000$} & \multirow[b]{2}{*}{\begin{tabular}{|c|} 
Ratio Z:P \\
at \\
present
\end{tabular}} & \multirow[b]{2}{*}{$\begin{array}{l}\text { Ratio } \\
Z: P \text { at } \\
\text { future }\end{array}$} \\
\hline & & & $\mathrm{SST}^{1}$ & netPP ${ }^{2}$ & \begin{tabular}{|c|}
$\begin{array}{c}\text { Phytoplankton } \\
\text { Biomass }^{2}\end{array}$ \\
\end{tabular} & $\begin{array}{l}\text { Zooplankton } \\
\text { Biomass }^{2}\end{array}$ & $\begin{array}{l}\text { Phytoplankton } \\
\text { Biomass from } \\
\text { Global model }\end{array}$ & $\begin{array}{l}\text { Zooplankton } \\
\text { Biomass from } \\
\text { Global model }\end{array}$ & & \\
\hline \multirow{2}{*}{\multicolumn{2}{|c|}{ Global }} & $\begin{array}{l}\text { Mean } \pm \\
\mathrm{SE}^{3}\end{array}$ & $2.29 \pm 0.05$ & $-0.092 \pm 0.004$ & $-0.058 \pm 0.002$ & $-0.107 \pm 0.003$ & - & - & 1.74 & 1.66 \\
\hline & & $\begin{array}{l}\text { Spatial } \\
\text { variability }\end{array}$ & Low & High & High & High & - & - & & \\
\hline \multirow{2}{*}{\multicolumn{2}{|c|}{ Barents Sea }} & $\begin{array}{l}\text { Mean } \pm \\
\mathrm{SE}^{3}\end{array}$ & $1.69 \pm 0.12$ & $\begin{array}{c}0.033 \\
{ }^{\mathrm{ns}} \pm 0.025\end{array}$ & $-0.278 \pm 0.021$ & $0.916 \pm 0.065$ & $0.078 \pm 0.18$ & $0.062 \pm 0.12$ & 0.05 & 0.13 \\
\hline & & $\begin{array}{l}\text { Spatial } \\
\text { variability }\end{array}$ & Low & Large & High & High & High & High & & \\
\hline \multirow{2}{*}{\multicolumn{2}{|c|}{ Baltic Sea }} & $\begin{array}{l}\text { Mean } \pm \\
\mathrm{SE}^{3}\end{array}$ & $3.04 \pm 0.28$ & $0.151 \pm 0.031$ & $0.139 \pm 0.032$ & $0.123 \pm 0.034$ & $-0.154 \pm 0.14$ & $-0.150 \pm 0.12$ & 0.15 & 0.15 \\
\hline & & $\begin{array}{l}\text { Spatial } \\
\text { variability }\end{array}$ & Medium & Medium & Medium & Medium & Moderate & Moderate & & \\
\hline \multirow{2}{*}{\multicolumn{2}{|c|}{$\begin{array}{l}\text { Atlantic } \\
\text { Margin }^{4}\end{array}$}} & $\begin{array}{l}\text { Mean } \pm \\
\mathrm{SE}^{3}\end{array}$ & $2.63 \pm 0.07$ & $-0.06 \pm 0.012$ & $-0.117 \pm 0.013$ & $-0.077 \pm 0.011$ & $-0.128 \pm 0.13$ & $-0.146 \pm 0.14$ & 0.83 & 0.87 \\
\hline & & $\begin{array}{l}\text { Spatial } \\
\text { variability }\end{array}$ & Low & High & High & High & Moderate & Moderate & & \\
\hline \multirow{2}{*}{\multicolumn{2}{|c|}{$\begin{array}{l}\text { Greater } \\
\text { North } \\
\text { Sea }^{4}\end{array}$}} & $\begin{array}{l}\text { Mean } \pm \\
\mathrm{SE}^{3}\end{array}$ & $3.08 \pm 0.101$ & $0.032^{\text {ns }} \pm 0.018$ & $-0.122 \pm 0.017$ & $-0.069 \pm 0.0159$ & $-0.150 \pm 0.06$ & $-0.141 \pm 0.05$ & 1.05 & 1.11 \\
\hline & & $\begin{array}{l}\text { Spatial } \\
\text { variability }\end{array}$ & Low & High & High & Low & Low & Low & & \\
\hline \multirow{8}{*}{ 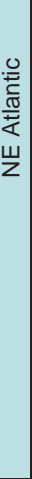 } & \multirow{2}{*}{$\begin{array}{l}\text { Greater } \\
\text { North } \\
\text { Sea }\end{array}$} & $\begin{array}{l}\text { Mean } \pm \\
\mathrm{SE}^{3}\end{array}$ & $2.82 \pm 0.03$ & $-0.125 \pm 0.027$ & $-0.061 \pm 0.009$ & $-0.198 \pm 0.064$ & $-0.150 \pm 0.06$ & $-0.141 \pm 0.05$ & 0.33 & 0.28 \\
\hline & & $\begin{array}{l}\text { Spatial } \\
\text { variability }\end{array}$ & Medium & High & High & High & Low & Low & & \\
\hline & \multirow{2}{*}{$\begin{array}{l}\text { Celtic } \\
\text { Sea }^{4}\end{array}$} & $\begin{array}{l}\text { Mean } \pm \\
\mathrm{SE}^{3}\end{array}$ & $2.65 \pm 0.12$ & $0.03^{\mathrm{ns}} \pm 0.024$ & $-0.032 \pm 0.000$ & $-0.01^{\mathrm{ns}} \pm 0.021$ & - & - & 0.95 & 0.95 \\
\hline & & $\begin{array}{l}\text { Spatial } \\
\text { variability }\end{array}$ & Low & High & High & High & - & - & & \\
\hline & \multirow{2}{*}{$\begin{array}{l}\text { Bay of } \\
\text { Biscay }\end{array}$} & $\begin{array}{l}\text { Mean } \pm \\
\mathrm{SE}^{3}\end{array}$ & $2.22 \pm 0.11$ & $-0.02 \pm 0.016$ & $-0.049 \pm 0.021$ & $-0.01^{\mathrm{ns}} \pm 0.019$ & $-0.193 \pm 0.03$ & $-0.307 \pm 0.02$ & 0.84 & 0.86 \\
\hline & & $\begin{array}{l}\text { Spatial } \\
\text { variability }\end{array}$ & Low & High & High & High & Low & Low & & \\
\hline & \multirow{2}{*}{$\begin{array}{l}\text { Bay of } \\
\text { Biscay }^{5}\end{array}$} & $\begin{array}{l}\text { Mean } \pm \\
\mathrm{SE}^{3}\end{array}$ & $3.49 \pm 0.09$ & $\mathrm{~N} / \mathrm{A}$ & $0.109 \pm 0.032$ & $0.44 \pm 0.02$ & $-0.193 \pm 0.03$ & $-0.307 \pm 0.02$ & 0.39 & 0.45 \\
\hline & & $\begin{array}{l}\text { Spatial } \\
\text { variability }\end{array}$ & Low & $\mathrm{N} / \mathrm{A}$ & High & High & Low & Low & & \\
\hline \multirow{2}{*}{\multicolumn{2}{|c|}{ Black Sea }} & $\begin{array}{l}\text { Mean } \pm \\
\mathrm{SE}^{3}\end{array}$ & $3.64 \pm 0.19$ & $0.052 \pm 0.09$ & $0.054 \pm 0.032$ & $-0.013^{\mathrm{ns}} \pm 0.24$ & - & - & 0.10 & 0.09 \\
\hline & & $\begin{array}{l}\text { Spatial } \\
\text { variability }\end{array}$ & Low & High & High & High & - & - & & \\
\hline \multirow{2}{*}{\multicolumn{2}{|c|}{ Adriatic Sea }} & $\begin{array}{l}\text { Mean } \pm \\
\mathrm{SE}^{3}\end{array}$ & $1.75 \pm 0.11$ & $0.162 \pm 0.026$ & $-0.004^{\mathrm{ns}} \pm 0.047$ & $0.019^{n s} \pm 0.095$ & - & - & 0.09 & 0.09 \\
\hline & & $\begin{array}{l}\text { Spatial } \\
\text { variability }\end{array}$ & $\mathrm{N} / \mathrm{A}$ & $\mathrm{N} / \mathrm{A}$ & $\mathrm{N} / \mathrm{A}$ & $\mathrm{N} / \mathrm{A}$ & - & - & & \\
\hline \multirow{2}{*}{\multicolumn{2}{|c|}{ Aegean Sea }} & $\begin{array}{l}\text { Mean } \pm \\
\mathrm{SE}^{3}\end{array}$ & $1.02 \pm 0.07$ & $\begin{array}{c}- \\
0.0425 \pm 0.012\end{array}$ & $-0.046 \pm 0.008$ & $-0.046 \pm 0.009$ & - & - & 0.48 & 0.48 \\
\hline & & $\begin{array}{l}\text { Spatial } \\
\text { variability }\end{array}$ & Medium & High & High & High & - & - & & \\
\hline \multirow{2}{*}{\multicolumn{2}{|c|}{$\begin{array}{l}\text { Benguela } \\
\text { Upwelling }\end{array}$}} & $\begin{array}{l}\text { Mean } \pm \\
\mathrm{SE}^{3}\end{array}$ & $1.36 \pm 0.07$ & $-0.12 \pm 0.002$ & $-0.148 \pm 0.014$ & $-0.126 \pm 0.012$ & $-0.040 \pm 0.06$ & $-0.080 \pm 0.07$ & 1.37 & 1.41 \\
\hline & & $\begin{array}{l}\text { Spatial } \\
\text { variability }\end{array}$ & Low & High & High & High & Low & Low & & \\
\hline
\end{tabular}

${ }^{1}$ Absolute difference

${ }^{2}$ Fractional change $=\left(\right.$ Scenario $\left._{(2080-2100)} / \mathrm{PD}_{(1980-2000)}\right)-1(-1$ to 0 : decrease, positive values: increase

${ }^{3}$ ns: not significant statistically, according to Kruskal-Wallis test.

${ }^{4}$ POLCOMS-ERSEM model.

${ }^{5}$ ROMS-NPZD model.

${ }^{6}$ ECOSMO 